\title{
APONTAMENTOS SOBRE AS INTERVENÇÕES ARQUEOLÓGICAS NO SÍTIO ESCOLA TERRAS DE CALDEIRÃOZINHO, MUNICÍPIO DE JUREMA, PIAUÍ
}

\author{
NOTES ON THE ARCHAEOLOGICAL INTERVENTIONS IN \\ THE SITE TERRAS DE CALDEIRÃOZINHO, MUNICÍPIO DE \\ JUREMA COUTY, PIAUÍ
}

\author{
Alencar de Miranda Amaral ${ }^{1}$ \\ alencar.amaral@univasf.edu.br \\ Vanessa Linke Salvio ${ }^{1}$ \\ vanessa.linke@univasf.edu.br \\ Waldimir Maia Leite Neto ${ }^{1}$ \\ waldimir.leiteneto@univasf.edu.br
}

\section{RESUMO}

Este relatório versa sobre as atividades desenvolvidas no âmbito do Projeto Sítio Escola Terras de Caldeirãozinho por docentes e discentes do Colegiado de Arqueologia e Preservação Patrimonial da Univasf. Mais especificamente, o texto em tela apresenta os sítios arqueológicos identificados durante as prospecções realizadas em 2017 no distrito de Caldeirãozinho, município de Jurema - Piauí; bem como, descreve as atividades de escavação empreendidas, no mesmo ano, em um dos sítios localizados (Sítio Terras do Maninho). Além de ampliar a gama de informações sobre o contexto arqueológico local e regional, especialmente a temas atinentes a Arqueologia do Presente e Arqueologia do Campesinato, os trabalhos desenvolvidos destacam-se por seu caráter didáticopedagógico e pelos desafios inerentes ao ensino da prática arqueológica.

Palavras chaves: Sítio Escola Terras de Caldeirãozinho, Prospecção, Escavação.

\footnotetext{
${ }^{1}$ Departamento de Arqueologia e Preservação Patrimonial, Univasf.
} 


\begin{abstract}
This report deals with the activities carried out within the framework of the Project Sítio Escola Terras de Caldeirãozinho by professors and students of Archeology of Universidade Federal do Vale do São Francisco (UNIVASF). More specifically, the text presents the archaeological sites identified during the surveys conducted in 2017 in the district of Caldeirãozinho, Jurema municipality - Piauí; as well as describes the excavation activities undertaken in the same year in one of the localized sites (Sítio Terras do Maninho). In addition to expanding the range of information on the local and regional archaeological context, especially the themes related to Archeology of the Present and Archeology of the Peasantry, the works developed stand out for their didactic-pedagogical character and the challenges inherent to the teaching of archaeological practice.
\end{abstract}

Keywords: Sítio Escola Terras de Caldeirãozinho; Prospection; Excavation.

\title{
CONTEXTUALIZAÇÃO DA PESQUISA
}

O Projeto Sítio Escola Terras de Caldeirãozinho vem sendo desenvolvido para atender as demandas do Curso de Arqueologia e Preservação Patrimonial da Universidade Federal do Vale do São Francisco - UNIVASF, o qual requer em seu Plano Didático Pedagógico disciplinas de prospecção e escavação em contextos coloniais e com temporalidades posteriores à invasão europeia.

O projeto passou a ser pensado no ano de $2017^{2}$ a partir do contato de um discente $^{3}$ do referido curso que procurou um dos professores responsáveis pelas disciplinas informando que nas terras de seu avô há anos aparece material arqueológico em superfície, nas áreas hoje reservadas ao plantio e pastagem.

\footnotetext{
${ }^{2}$ Ano para o qual se obteve portaria de autorização de pesquisa junto ao IPHAN (Portaria ${ }^{\circ} 42 \mathrm{de}$ 04 de agosto de 2017; Processo n. ${ }^{\circ} 01402.000521 / 2017-53$ ).

${ }^{3}$ Aproveitamos para publicizar nossos agradecimentos a Lucas Assis Ribeiro e seus familiares, bem como a todos os colaboradores (proprietários e moradores) de Caldeirãozinho.
} 
Tendo-se organizado uma visita técnica ao local, conhecido por Jatobá dos Ferros, no distrito de Caldeirãozinho, município de Jurema - Piauí, verificou-se, a partir do caminhamento oportunístico e relatos orais, o potencial arqueológico da área e sua adequação para o desenvolvimento de atividades com fins didáticopedagógicos.

As primeiras atividades prospectivas, não interventivas, possibilitaram a identificação de estruturas edificadas correspondentes a moradias abandonadas, casa de farinha e um sem número de artefatos e fragmentos de material construtivo. Vale notar que entre os materiais arqueológicos nitidamente correspondentes, do ponto de vista temporal, ao contexto chamado de histórico se encontravam também artefatos líticos (polidos e lascados), que poderiam corresponder a uma ocupação pré-colonial, ou uma ocupação indígena em contexto histórico.

Nos meses de setembro e outubro de 2017 foram realizadas as primeiras escavações vinculadas ao projeto. As mesmas ficaram restritas a uma porção de terras de Jatobá dos Ferros, correspondentes às Terras de Seu Maninho. Durante as atividades foram também realizadas coletas de superfície amostral comtemplando, sobretudo os artefatos em vidro e os artefatos líticos polidos e lascados. Nesta etapa foi gerado um acervo de 2675 peças, incluindo entre elas fragmentos de material construtivo (como telhas e manilhas), louças, vidros, metal, cerâmicas regionais e cerâmicas simples possivelmente pré-coloniais. 
No contexto das duas etapas de campo foram ainda realizadas atividades oportunísticas de diálogo e coletadas informações orais com a comunidade de Jatobá dos Ferros, e também com moradores do contexto urbano de Caldeirãozinho, a fim de se iniciar uma aproximação entre os pesquisadores e a pesquisa realizada pela UNIVASF com a comunidade local, informando-a de nossa presença e gerando as primeiras impressões da mesma quanto ao patrimônio arqueológico local, bem como seus modos de compreender a historicidade de ocupação e vivência de Jatobá dos Ferros.

Neste mister, o material ora apresentado, refere-se às reflexões e atividades delineadas em Jatobá dos Ferros no âmbito das disciplinas de prospecção (Métodos e Técnicas 3) e escavação arqueológica (Métodos e Técnicas 4) promovidas pelo Colegiado de Arqueologia e Preservação Patrimonial da UNIVASF durante o ano letivo de 2017.

\section{SÍTIOS ARQUEOLÓGICOS ATÉ ENTÃo IDENTIFICADOS DURANTE AS PROSPECÇÕES}

Para a identificação das possíveis áreas de interesse arqueológico foram empregados métodos já consagrados na literatura sobre o planejamento e execução de prospecções arqueológicas. Como observado por Bicho (2006:91), os trabalhos prospectivos não se limitam à identificação de novos sítios arqueológicos, devendo ser entendidos como ferramenta privilegiada para o escrutínio de como o espaço e a paisagem foram organizados e explorados pelos 
seres humanos. Nesse sentido, por intermédio das prospecções podemos angariar informações para a análise espacial da distribuição dos sítios arqueológicos na paisagem, e das formas de interação dos seres humanos com o seu ambiente circundante e dos padrões de articulação entre eles.

Tendo em mente estes princípios, os caminhamentos foram realizados buscandose tanto a identificação dos artefatos e estruturas arqueológicas quanto a caracterização físico-biótica dos sítios localizados, delimitação de sítios arqueológicos e da distribuição de artefatos, estruturas ou outros tipos de vestígios. Optou-se, pela alternância entre os métodos sistemático intensivo e o assistemático extensivo, ou oportunístico (SANJÚAN, 2005). Do ponto de vista prático, foi adotada a estratégia de caminhamentos de varredura, ou linhas de caminhamento, com um grau de intensidade médio, tendo as distâncias entre os prospectores variado entre 2 a $10 \mathrm{~m}$, dependendo da visibilidade do terreno. Os materiais (artefatos e estruturas) foram fotografados e georeferenciados, com uso de GPS de navegação.

Nos primeiros caminhamentos sistemáticos que fizemos identificamos em quatro áreas, correspondentes a propriedades rurais distintas (Figura 1), vestígios de ocupação que parecem corresponder à cultura material dos que ali viveram desde de tempo pré-coloniais até os dias atuais. Assim, os sítios identificados foram denominados: Terras de Seu Salvador; Terras de Seu Zeba; Terras de Seu Olinto e Terras de Seu Maninho. 
Área de Estudo Terras do Caldeirãozinho, UNIVASF
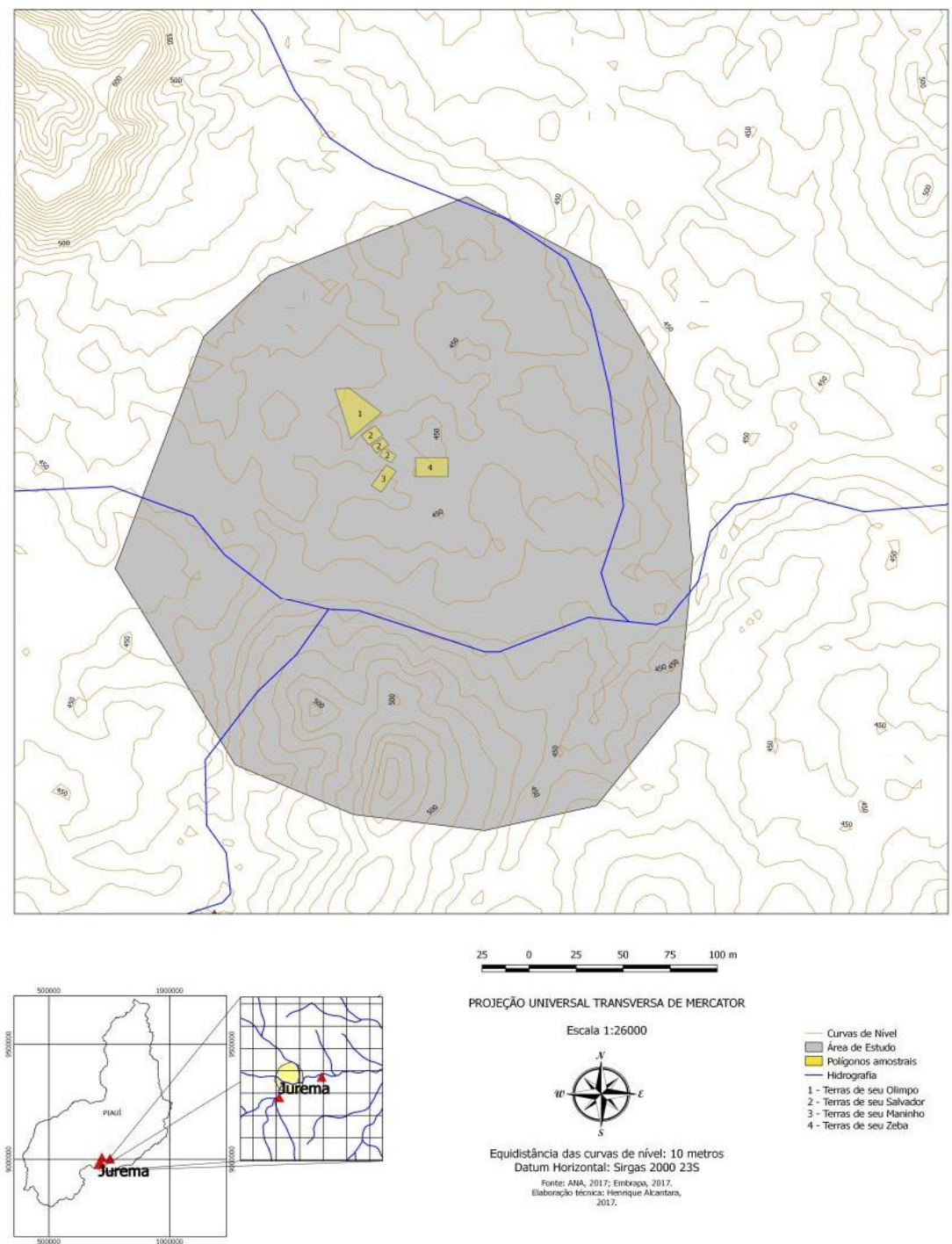

PROJEÇÃO UNIVERSAL TRANSVERSA DE MERCATOR

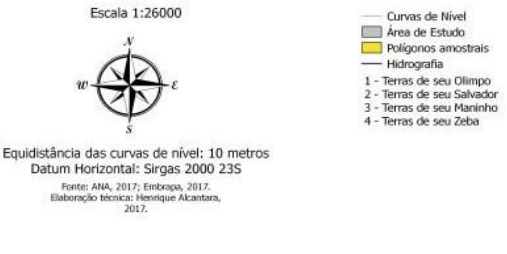

Figura 1: Mapa da área de pesquisa com localização dos polígonos referentes às áreas nas quais foram realizados caminhamento por varredura. 


\section{Sítio Terras de Seu Salvador}

As terras de Seu Salvador são caracterizadas por áreas de plantio, pastagem e por uma porção da Lagoa de São Felix (Figura 2). Na área, foram identificados materiais construtivos, assim como louça, vidro, olaria e material lítico.

A área possui feições de relevo que tendem de planas à suavemente onduladas, sendo a área mais acidentada aquela correspondente aos limites da Lagoa de São Felix. Segundo, informações recolhidas com o proprietário, Seu Salvador, na área da lagoa era retirado "barro" para a fabricação de telhas e vasilhas cerâmicas. Contudo, não identificamos no local a área de extração, nem restos de fornos ou outras estruturas que poderiam estar relacionadas à extração e uso da argila para fabricação de olaria e demais artefatos cerâmicos.

Além dos materiais arqueológicos identificados, vale mencionar a presença de espécies vegetais que parecem marcar a paisagem e se relacionar às histórias afetivas de ocupação e relação com o lugar e os demais seres que o habitam. Vale destacar a presença de um mandacaru (Figura 3) frequentemente referido pelos moradores como local de mortes e brigas. Não pouco frequentes foram os relatos de Seu Salvador com relação às brigas e mortes, bem como aos enterramentos acompanhados de lajes, as quais eram marcadas com sangue dos mortos. Todavia, não identificamos locais que poderiam corresponder a tais sepulturas. 


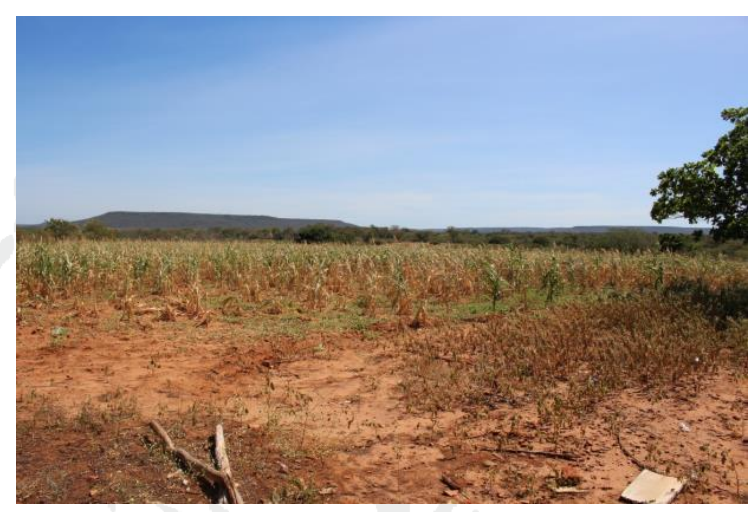

Figura 2: Vista da área de plantio de milho nas Terras de Seu Salvador.

Figura 3: Mandacaru presente nas Terras de Seu Salvador e constantemente vinculado ao local de mortes e brigas.

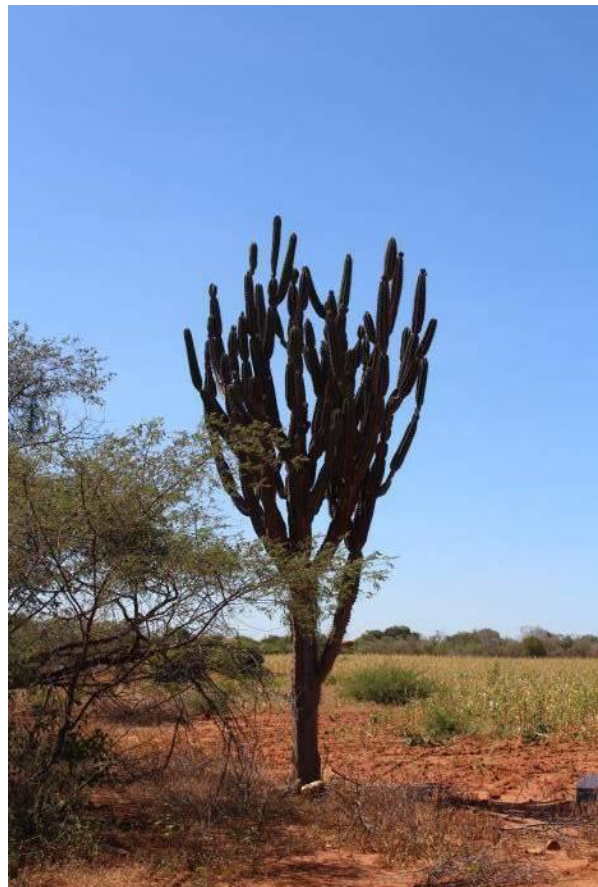

\section{Sítio Terras de Seu Zeba}

As Terras de Seu Zeba, assim como as de Seu Salvador, possui relevo plano a suavemente ondulado. Contudo, em sua porção mais meridional o relevo tende a ser mais acidentado, marcando o limite da vertente com a planície de inundação do rio.

Nas Terras de Seu Zeba tem-se uma edificação correspondendo a sua atual casa, além de uma estrutura arruinada correspondente a sua habitação anterior. Há ainda mais duas estruturas que podem se referir a duas antigas habitações. Seu Zeba nos 
informou que dentro da área de suas terras já existiram quatro casas nas quais ele e seus familiares moraram em tempos passados. De uma delas ele se mudou em decorrência da morte do filho.

A estrutura edificada correspondente a sua última habitação, da qual se mudou a aproximadamente 10 anos (Figura 4), momento em que passou a ter luz em seu terreno, localiza-se próximo à sua atual morada e suas ruinas parecem fazer parte da área de descarte de lixos e artefatos atual ${ }^{4}$.

Para além dos vestígios de habitações, foram encontrados fragmentos cerâmicos, lítico, olarias, metal, vidro, plástico.

Seu Zeba nos informou que na porção de seu terreno, chamada de tanque (que parece corresponder a uma atual estrutura de aprisionamento hídrico), haviam barreiros e fornos coletivos para produção de olaria para consumo local, familiar, mas também regional. Todavia, devido as dificuldade acesso, na ocasião, não realizamos atividades prospectivas neste local.

\footnotetext{
${ }^{4}$ Ver discussão em Nascimento (2011) sobre o uso dos quintais e terreiros nos processos de uso e descarte de materiais arqueológicos.
} 


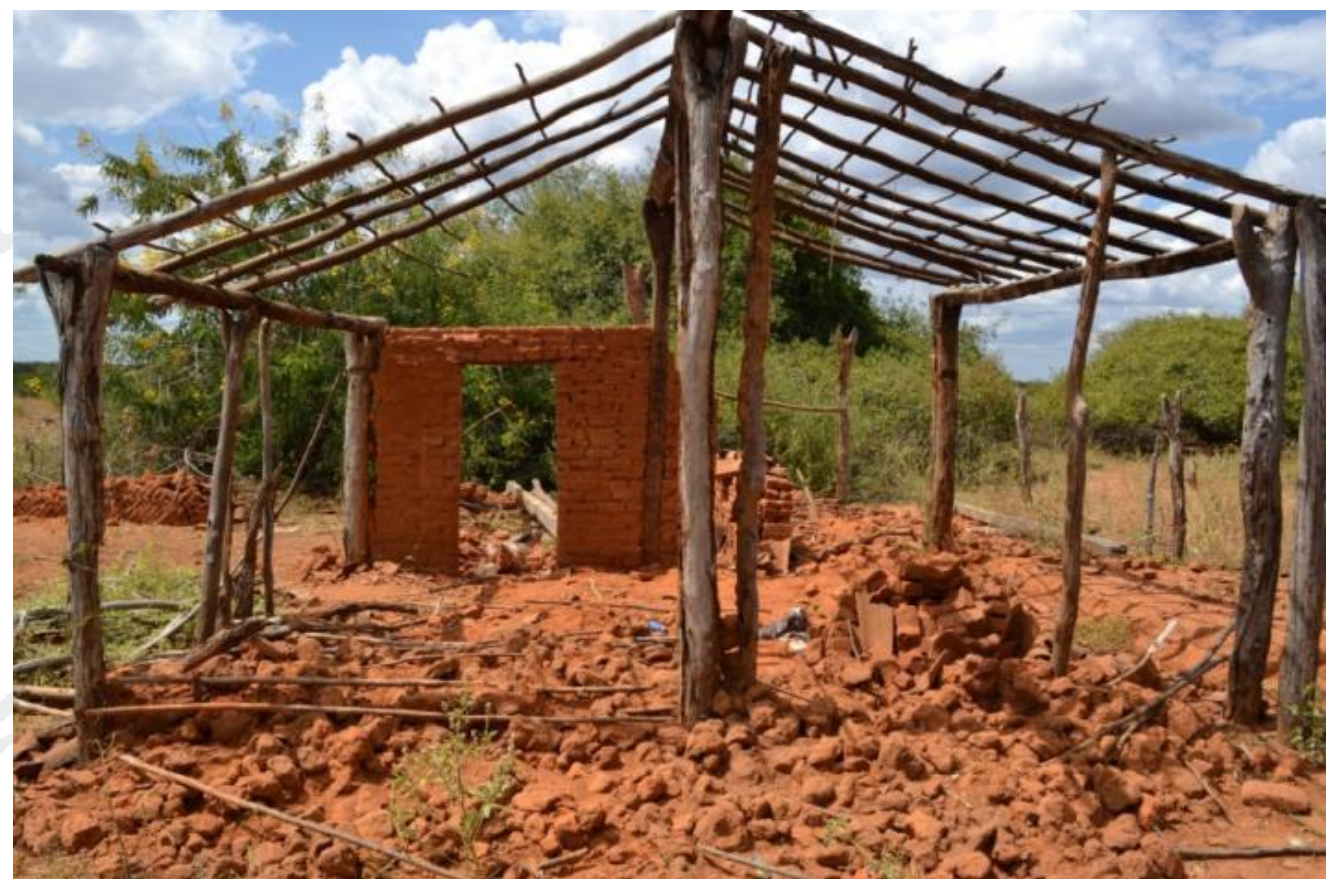

Figura 4: Edificação correspondente a última moradia de Seu Zeba e família.

\section{Terras de Seu Olinto}

Nas terras de Seu Olinto o relevo configura-se como suavemente ondulado com área de quebra mais marcadas nas vertentes. $\mathrm{Na}$ área foram localizadas uma estrutura edificada de habitação e estruturas de uma antiga casa de farinha (Figuras 5 e 6). Vários materiais arqueológicos podem ser observados em superfície, como artefatos líticos, cerâmica, louça, vidro e metal. 

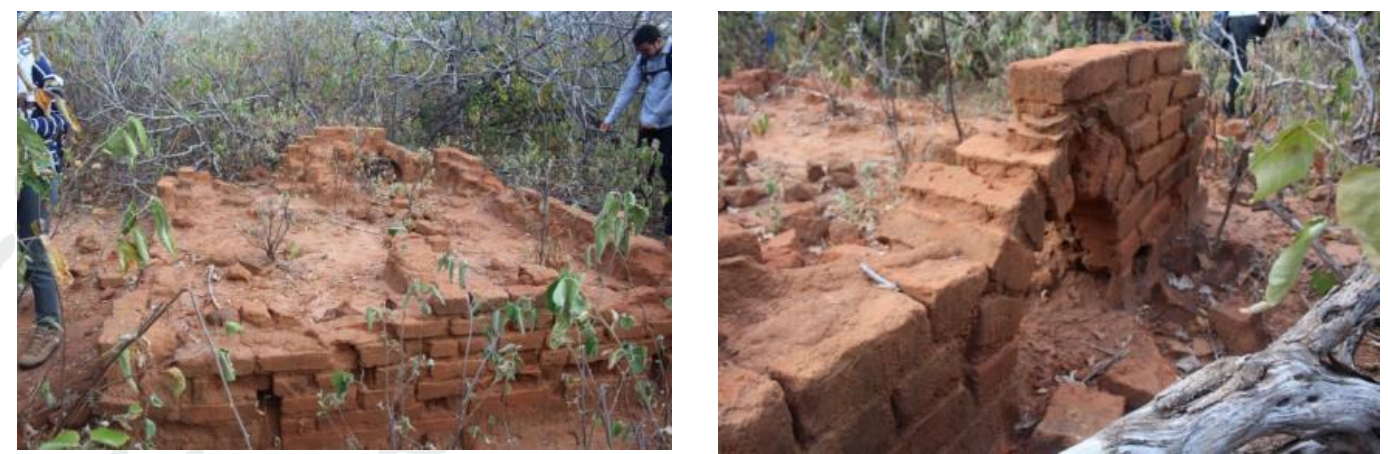

Figuras 5 e 6: Estruturas vinculadas à Casa de Farinha das Terras de Seu Olinto.

\section{Terras de Seu Maninho}

As terras de Seu Maninho correspondem a área com o maior número de vestígios identificados; englobando, ainda, a estrutura de uma edificação que, segundo o próprio Seu Maninho, corresponde à casa em que parte de seus filhos nasceram. Desta casa, que, segundo as informações orais seria de taipa, pouco restou. Vimos apenas alguns montículos de material construtivo. Vê-se ainda no terreno ruinas da antiga casa de farinha, estruturas ligadas a criação de animais, um barreiro, montículos de material construtivo que poderiam corresponder a outras habitações. Inclusive aquela que foi da mãe de Seu Maninho, atualmente utilizada como ponto de apoio nas atividades agrícolas, mas que no passado abrigou um bar e a casa que a família habitava antes de se mudarem para a zona urbana de Caldeirãozinho. No local, ainda é possível identificar os "potes" de armazenar água, hoje quebrados, que faziam parte da tralha doméstica da família (Figura 7). 
Além destas estruturas, nas narrativas das pessoas da comunidade, são recorrentes histórias sobre um pote de cerâmica enterrado na área do umbuzeiro das Terras de Seu Maninho, o qual foi identificado através de intervenções dos moradores na área da árvore. Segundo os mesmos, após destampado e descoberto ossos que pareciam humanos, o pote e seus conteúdos foram deixados no mesmo lugar.

Em função das expectativas diante da suposta "botija" não realizamos intervenções na área, a fim de que a mesma possa ser no futuro, momento em que esperamos ter mais informações a respeito do processo de ocupação local, estratigrafia e maior clareza das expectativas da comunidade quanto a estrutura, seus significados, anseios, possa ser escavada.

Além das estruturas citadas, a área apresenta grande quantidade e dispersão de materiais em subsuperfície, tendo sido identificados fragmentos cerâmicos, artefatos líticos (Figura 8), além de louças, vidro, plástico, metal e material construtivo. 


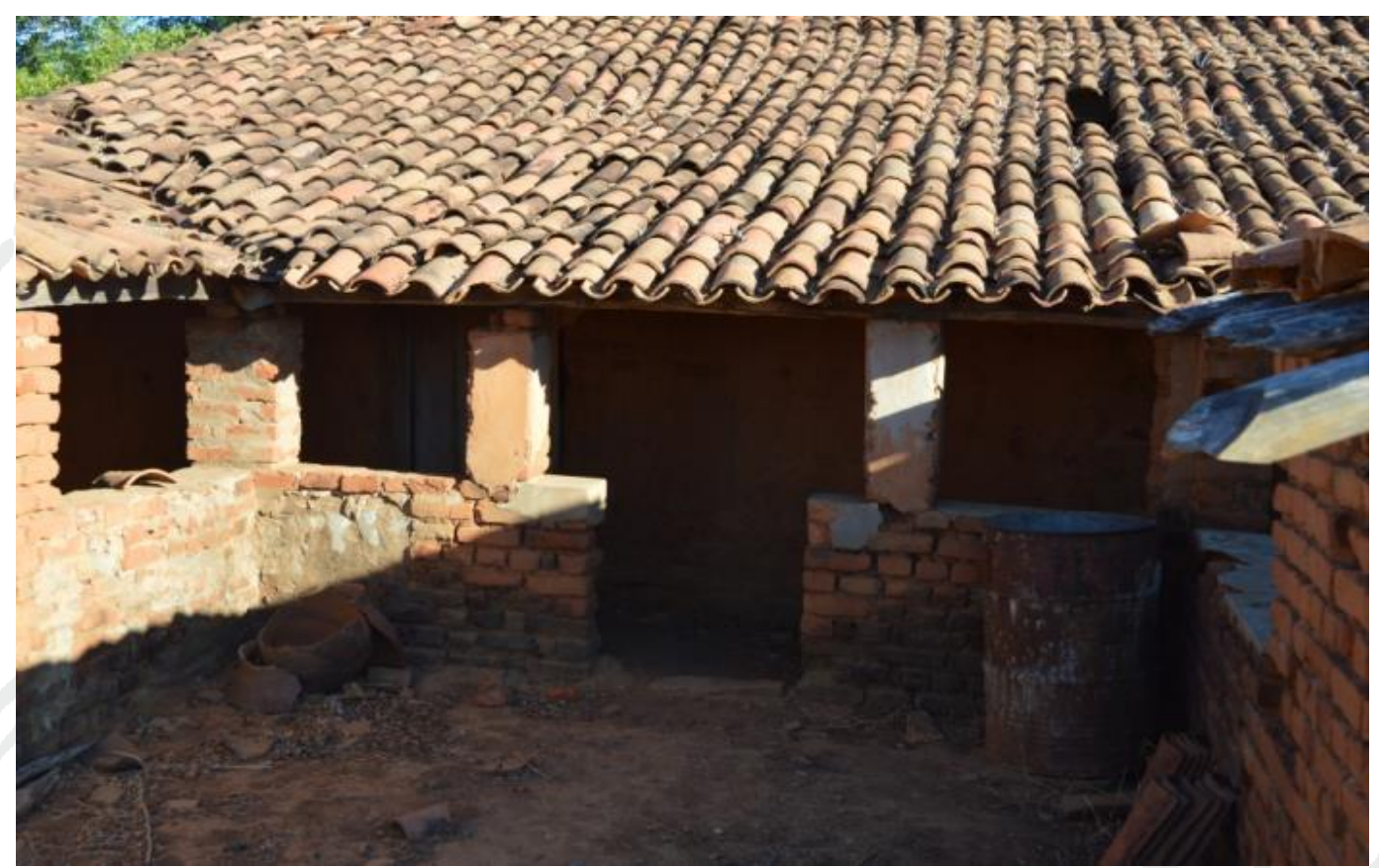

Figura 7: Estrutura edificada que corresponde a antiga habitação e bar (bodega) de Seu Maninho, com fragmentos do "pote d'água" no canto inferior esquerdo.

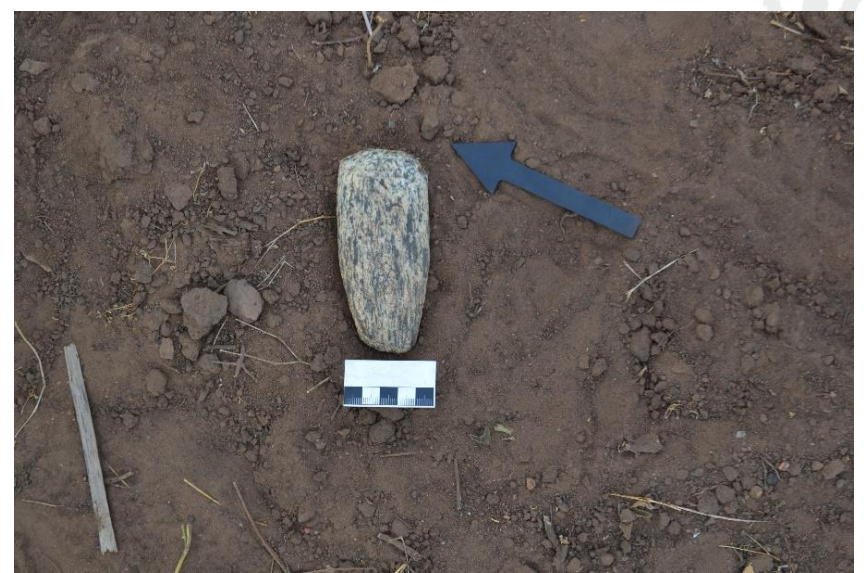

Figura 8: Artefato lítico: Machado polido encontrado no sítio Terras de Maninho. 


\section{ATIVIDADES DE ESCAVAÇÃO NO SÍTIO TERRAS DE MANINHO}

As atividades abordadas neste segmento do presente relatório foram realizadas entre os dias 19 de setembro a 05 de outubro de 2017, no âmbito da disciplina Métodos e Técnicas Arqueológicas IV, ofertada pelo curso de graduação em Arqueologia e Preservação Patrimonial da UNIVASF durante o semestre letivo 2017.1 .

A referida disciplina "visa fornecer aos estudantes a prática de escavação e registro arqueológico de sítios históricos e suas estratigrafias, estruturas, vestígios e artefatos, análise preliminar do material'. Assim, dentre seus objetivos podemos destacar: iniciar os alunos na prática e no desafio de empreender uma escavação arqueológica em contexto histórico; promover estratégias para a pesquisa de campo na arqueologia histórica; analisar e registrar os princípios da estratigrafia arqueológica do sítio; elaborar um projeto de pesquisa científica para o sítio arqueológico; promover a compreensão e a aplicação das técnicas de escavação, levantamento em desenho e fotografia de estruturas arqueológicas; levantamento e reflexão critica da documentação disponível para o sítio arqueológico (fontes escritas, orais, cartografia); promover a interpretação da escavação arqueológica através da elaboração de um relatório técnico das atividades de campo.

\section{Metodologia aplicada}

As intervenções executadas na área, de modo geral, inspiram-se nas técnicas clássicas das escavações arqueológicas por níveis naturais e registro da 
distribuição espacial dos artefatos e estruturas. Todavia, o caráter didático e pedagógico intrínseco ao projeto de pesquisa ao qual esse relatório se associa, também foi considerado como um fator relevante na escolha dos procedimentos adotados, bem como na presente descrição. Neste sentido, a definição dos processos e parâmetros hora apresentados são fruto das discussões realizadas com os discentes, e visavam tanto a adequada intervenção e registro do contexto arqueológico quanto uma compreensão e aprendizado das ações executadas.

Em uma perspectiva pragmática, o levantamento topográfico ${ }^{5}$ da área pesquisada foi realizado com o uso de uma Estação Total, e auxílio do técnico em topografia da Univasf, senhor Flávio Barros. Um dos objetivos desta etapa foi construir a documentação planialtimétrica da área, e assim, registrar as dimensões e condições do terreno onde o sítio está situado, a variação das cotas, a presença e localização de elementos paisagísticos e estruturas arqueológicas, bem como definir a malha topográfica da área a ser escavada.

A inexistência de levantamentos topográficos anteriores, e, por conseguinte, a ausência de marcos geodésicos já registrados nesta área, motivou-nos a executar um levantamento planialtimétrico cadastral, com a escolha e definição de pontos georeferenciados atinentes as necessidades dos trabalhos arqueológicos a serem

\footnotetext{
${ }^{5} \mathrm{O}$ levantamento topográfico pode ser divido em duas partes: o levantamento planimétrico, onde se procura determinar a posição planimétrica dos pontos (coordenadas $\mathrm{X}$ e $\mathrm{Y}$ ) e o levantamento altimétrico, onde o objetivo é determinar a cota ou altitude de um ponto (coordenada $\mathrm{Z}$ ). A realização simultânea dos dois levantamentos dá origem ao chamado levantamento planialtimétrico (VEIGA et al; 2012).
} 
realizados na área. Deste modo, tendo em consideração tanto o entorno do sítio como o perímetro a ser escavado, foi estabelecido o primeiro marco ou Datum principal (fuso 23, Norte (N) ('y') 1000; Leste (E) ('x') 1000, com elevação 457), que serviu como ponto base para instalação da estação total e início do levantamento topográfico (Figura 9).

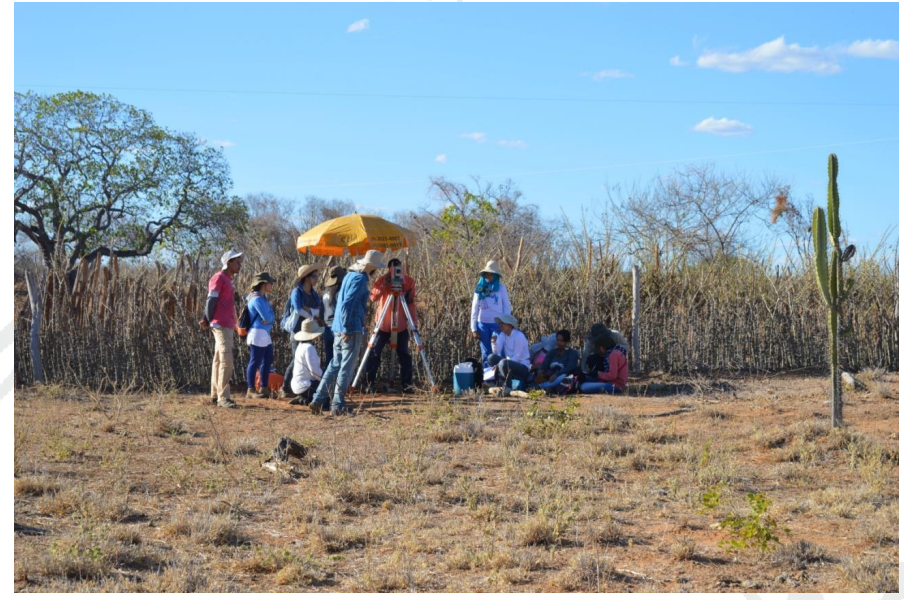

A determinação do local de instalação do marco geodésico levou em consideração tanto as demandas associadas ao trabalho arqueológico, quanto aquelas inerentes ao equipamento para o levantamento topográfico. Deste modo, optou-se pela orientação pelo norte magnético e escolha de um local que possibilitava a visualização de toda a área a ser escavada e do entorno do sítio. Com isto, de um único ponto (Datum principal), poderíamos ter uma visão total da área do sítio a ser escavada nesta campanha sem elementos que pudessem atrapalhar o uso da estação total. Cabe mencionar, que objetivando a manutenção de um único parâmetro para o georeferenciamento das futuras atividades a serem 
implementadas na área foi instalado um marco fixo (piquete de concreto) para demarcação do Datum principal (Figura 10).

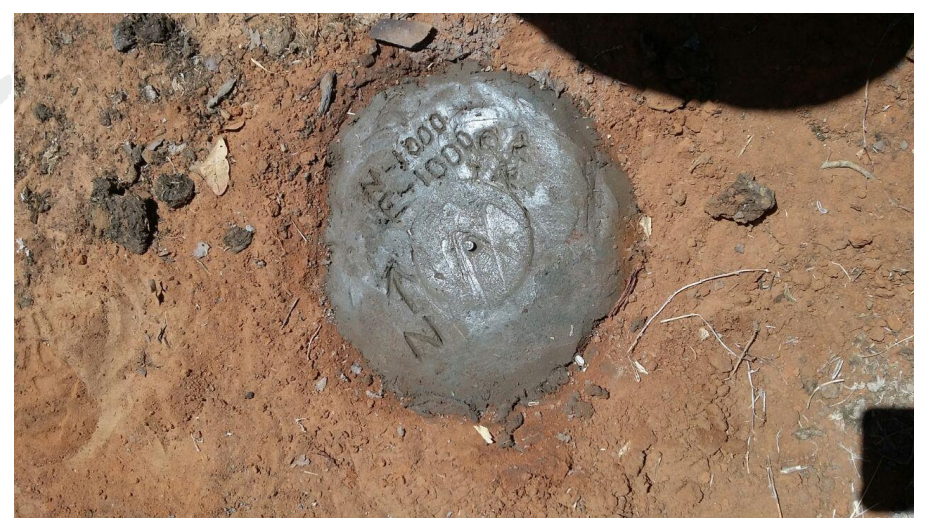

Figura 10: Imagem do

Datum.

Também é importante ressaltar que para a definição da malha topográfica, foi concedido um valor arbitrário ao Datum principal (N1000/E1000), com vistas a permitir que aquele marco possibilita-se o georeferenciamente de uma área de até $1000 \mathrm{~m}^{2}$, sem a necessidade do emprego de uma numeração negativa. Assim, tendo o Datum principal como "marco zero" para a realização das medições e os eixos cardeais como pontos de orientação é possível estabelecer/demarcar a planimetria de uma área extensa, isto porque a numeração segue uma ordem crescente no eixo N/E, e decrescente no eixo $\mathrm{S} / \mathrm{W}$. Ou seja, se um ponto esta a 100 metros a norte, ou leste, do Datum principal este valor é acrescido na marca préestabelecida (N1100/eE1100); e caso o ponto esteja localizado a 100 metros a sul ou oeste do Datum principal este valor será diminuído da marca inicial (N900/E900). 
Estes parâmetros foram empregados para a localização e registros de outros dois marcos fixos (Subdatum A: N1118.449/E1000, e Subdatum B: N846.309/E1000); de alguns piquetes móveis de madeira necessários para o levantamento do plano topográfico do terreno; e para definição dos grids que deram origem a delimitação e quadriculamento da área a ser escavada.

Após estabelecermos os meios e definirmos os parâmetros a serem empregados no levantamento topográfico da área e georeferenciamento da escavação, o procedimento seguinte foi determinar a área do sítio que seria alvo das intervenções arqueológicas. Assim, a escolha se deu tendo em consideração dois elementos do contexto arqueológico observados na superfície do sítio, a saber: dispersão/concentração de artefatos arqueológicos (louça, vidro, cerâmica, material construtivo, etc); presença de alterações edáficas (3 manchas) que poderiam estar associadas à ocupação ou utilização daquela área.

Objetivando compreender a correlação entre as alterações edáficas (manchas) e os artefatos arqueológicos, bem como o seu comportamento em sub-superfície, optou-se pela delimitação de duas sub-áreas de escavação. Uma no interior de uma mancha (setor leste/oeste), e outra fora do perímetro das alterações edáficas (setor norte/sul). Em cada uma das áreas foi estabelecida uma trincheira com um número variável de quadrículas de $1 \mathrm{~m}^{2}$. 
Na primeira área, denominada de Setor Norte/Sul foi demarcada uma trincheira de 4 metros de comprimento, totalizando quatro quadrículas de $1 \mathrm{~m}^{2}$ (N933/L1072, N934/L1072, N935/L1072 e N936/L1072). Na outra área, denominada Setor Leste/Oeste, delimitou-se um trincheira de 8 metros de extensão, dividida em oito quadrículas de 1m² (N928/L1075, N928/L1074, N928/L1073, N928/L1072, N928/L1071 e N928/L1070, N928/L1069 e N928/L1068), entretanto, somente quatro quadrículas deste setor foram escavadas (N928/L1075, N928/L1074, N928/L1073, N928/L1072) (Figuras 11, 12 e 13). A nomenclatura das quadrículas foi determinada por sua distância e posicionamento em relação ao marco geodésico fixado para representar o Datum principal.

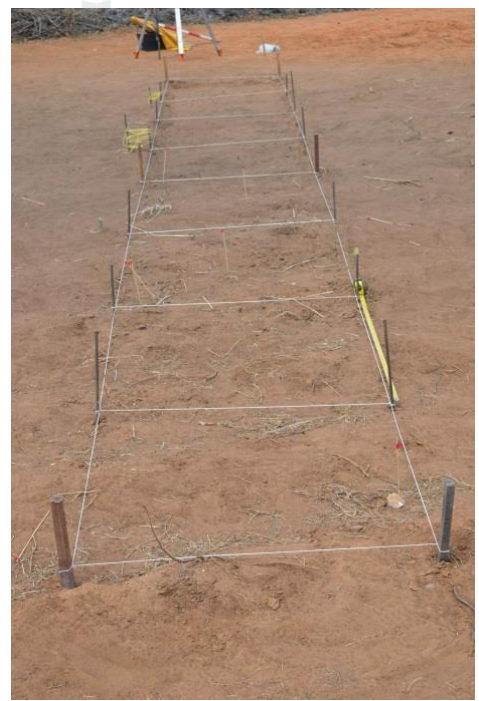

Setor Leste-Oeste

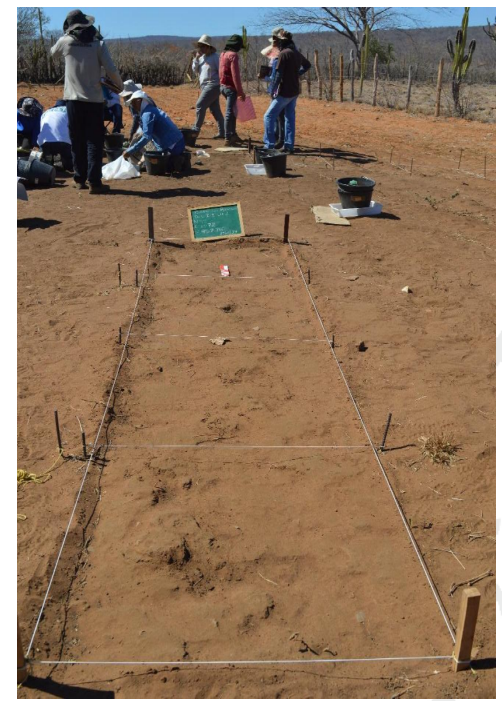

Setor Norte-Sul
Figura 11 e 12: Área de Escavação do Sítio Terras de Maninho. 


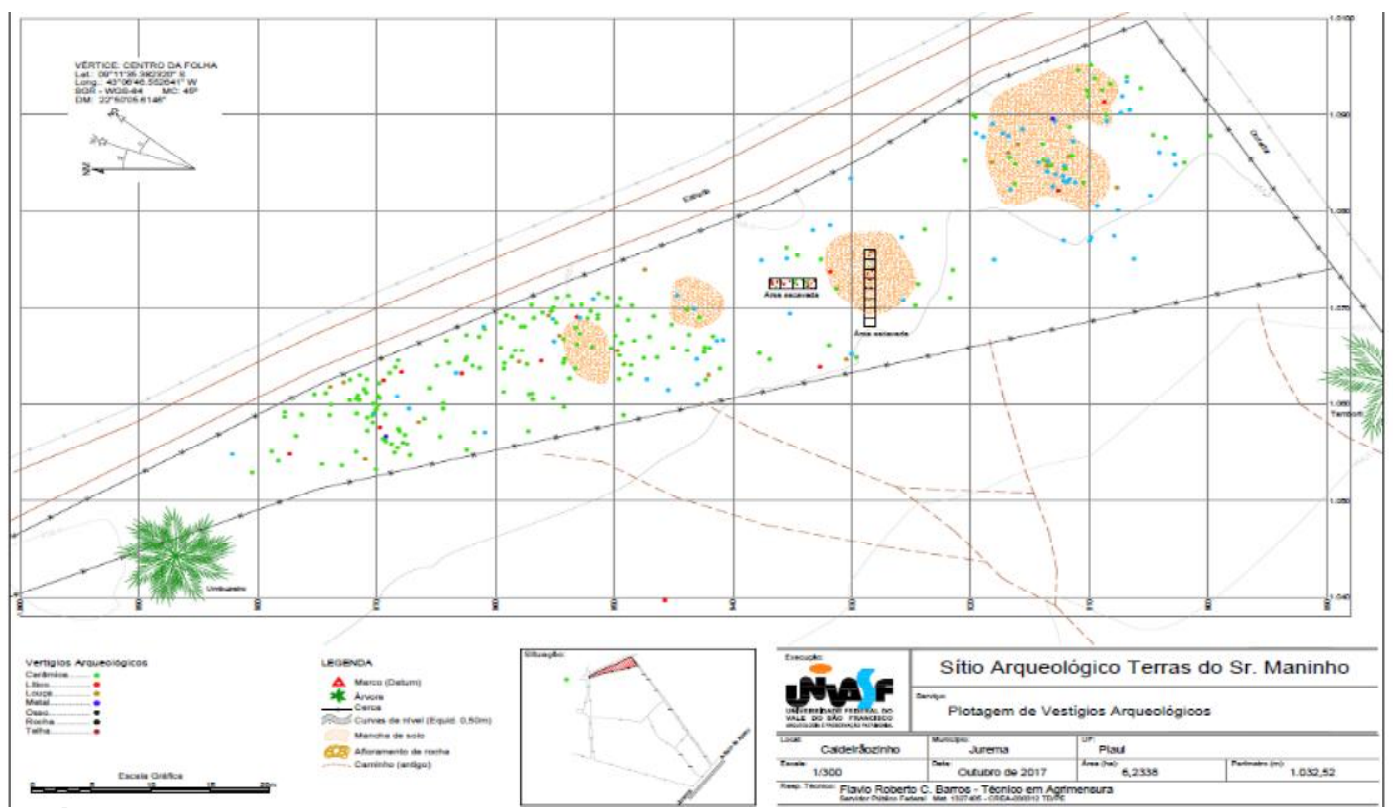

Figura 13: Área de Escavação do Sítio Terras de Maninho

$\mathrm{Na}$ execução das escavações arqueológicas optamos pela realização de decapagens efetuadas por níveis naturais, conforme a realidade apresentada por cada quadrícula. A escavação por decapagens consiste em seguir os momentos de deposição do solo arqueológico, reputando minuciosamente a manutenção in locu de todos os vestígios, privilegiando assim a sua evidenciação (LEROIGOURHAN e BRÉZILON, 1972: 321).

Assim, para o ataque horizontal, utilizamos instrumentos finos, como pincéis e colheres de arqueólogo (Figura 14), que nos permitiam evidenciar os artefatos arqueológicos sem alterar sua posição, e reconhecer e remover integralmente as 
unidades estratigráficas, respeitando o seu contorno e dimensões naturais. Deste modo, seguindo os preceitos dos processos de formação da estratigrafia arqueológica preconizados por Harris (1991), procurou-se sempre escavar os depósitos respeitando os seus próprios contornos naturais, sendo estes numerados e descritos como entidades individuais e retirados pela ordem inversa àquela em que foram depositados, de forma a possibilitar, para além da contextualização acertada dos respectivos materiais, a reconstituição da ordem sequencial de deposição das unidades estratigráficas.

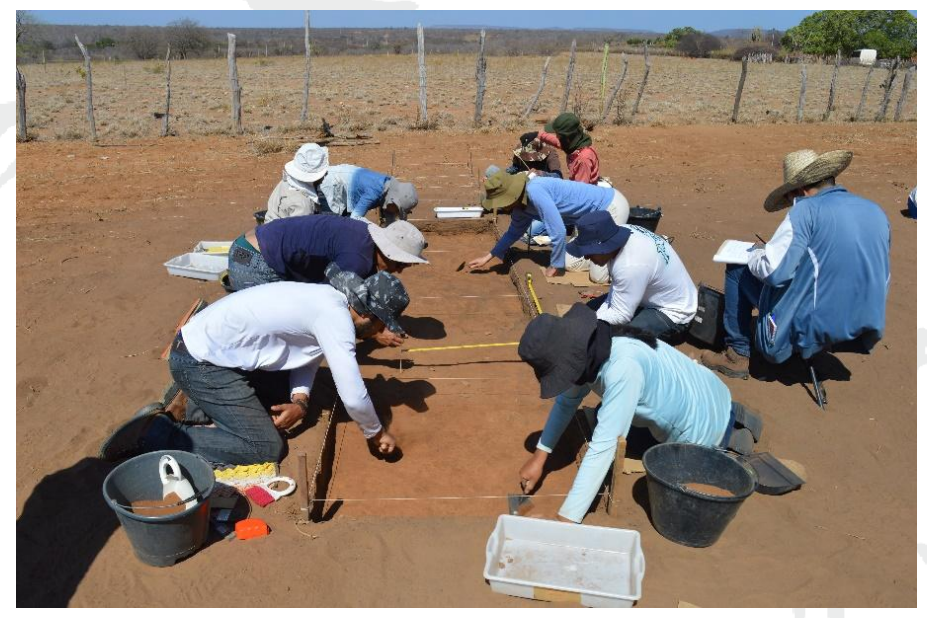

É importante destacar que apesar destes preceitos nortearem todas as intervenções implementadas em sub-superfície, devido ao caráter didático-pedagógico das atividades realizadas e da pouca experiência dos escavadores optou-se por realizar o registro documental (fichas), fotográfico e topográfico sempre que a retirada de sedimentos atingisse uma cota de $5 \mathrm{~cm}$ ou $6 \mathrm{~cm}$, mesmo quando não houvesse 
mudança na unidade estratigráfica. Ou seja, unidades estratigráficas que formavam camadas com mais de $6 \mathrm{~cm}$ foram decapadas gradativamente, com o intuito de prevenir a perda de informações contextuais.

Portanto, a decapagem cuidadosa, com a manutenção dos achados in locu e a notificação do posicionamento horizontal e vertical dos artefatos, sempre precedeu a coleta final de material, fornecendo dados capazes de embasar interpretações sobre a disposição dos artefatos e sua relação com os eventos de formação da estratigrafia arqueológica.

Assim, ao término da decapagem, cada quadrícula só poderia ter o material coletado após o registro geral das atividades realizadas, características do sedimento, e informações relevantes (número da decapagem, cota atingida, cor do sedimento segunda a escala colorimétrica Munsell Collor chart, compactação do sedimento, presença de bioturbações, etc.), e da plotagem/georeferenciamento, desenho e documentação fotográfica do material encontrado. Os fragmentos foram acondicionados em embalagens específicas, devidamente notificadas através de etiquetas seriadas contendo informações gerais (nome do sítio, quadrícula, decapagem, unidade estratigráfica, ponto topográfico etc.), atendendo às exigências necessárias para a interpretação da disposição dos artefatos. 
Além disso, todo sedimento removido foi peneirado e os fragmentos encontrados nesse processo eram etiquetados separadamente em conformidade com a quadrícula, decapagem e unidade estratigráfica a qual estavam associados.

Por fim, o registro das atividades realizadas nas escavações foi feito através de dois protocolos complementares. A caderneta de campo individual, na qual cada membro da equipe tinha a liberdade de descrever as atividades (individuais e coletivas) realizadas diariamente, bem como expressar suas impressões sobre o andamento e metodologia de trabalho, ou formulara análises iniciais sobre o contexto arqueológico. E uma série de fichas estandardizadas (ficha de decapagem; fichas de unidade estratigráfica; ficha/etiqueta de controle de lote; e ficha topográfica), destinadas a garantir a padronização no conteúdo e descrição das informações. Concomitantemente, também foi realizada a documentação imagética (registro fotográfico; desenho da planta baixa e do perfil das quadrículas; croquis da área de escavação) das atividades empreendidas em cada quadrícula, e do trabalho de campo de modo geral.

\section{DESCRIÇÃO DA ESCAVAÇÃO POR DECAPAGEM}

A seguir apresentaremos a descrição das atividades de escavação empreendidas nos Setores Norte/Sul e Leste/Oeste, bem como algumas informações iniciais sobre a diversidade e distribuição (vertical) dos artefatos e sua correlação com a estratigrafia da área escavada. Iniciaremos apresentando as intervenções do Setor 
Norte/Sul, onde foram escavadas as quatro quadrículas, denominadas: N933/L1072, N934/L1072, N935/L1072 e N936/L1072.

\section{Setor Norte/Sul}

\section{Quadrícula N933/L1072}

Nesta quadrícula foram efetuadas cinco decapagens, atingindo a cota máxima de $25 \mathrm{~cm}$ de profundidade. A primeira decapagem atingiu a cota máxima de $6 \mathrm{~cm}$ de profundidade, demarcado assim o limite da Unidade Estratigráfica 1 (UE1), que pode ser caracterizada como uma camada formada por sedimento pulverulento composto por areia média de tonalidade 10YR 4/3 Brown. Durante o processo de decapagem foram observadas bioturbações causadas por insetos (formigueiro), e evidenciados fragmentos de cerâmica, vidro, olaria (telha e tijolo), louça e plástico.

A segunda decapagem removeu o sedimento depositado entre 6 e $10 \mathrm{~cm}$ de profundidade, sendo referente a cota que a Unidade Estratigráfica 2 (UE2) atinge nesta quadrícula. A UE2 pode ser caracterizada como uma camada formada por sedimento pouco compacto composto por areia silte de tonalidade $7.5 \mathrm{YR}$ 4/3 Reddish Brown. Durante o processo de decapagem foram observadas bioturbações causadas por plantas e insetos (raízes e casulo de insetos), e evidenciados fragmentos cerâmica (Figura 15), olaria, metal, vidro e lítico. 
A terceira (entre 10 a $15 \mathrm{~cm}$ ) e a quarta decapagem (entre 15 e $20 \mathrm{~cm}$ ), referem-se em grande parte a retirada de sedimentos associados a Unidade Estratigráfica 3 (EU3). A UE3 pode ser caracterizada como uma camada formada por por sedimento pouco compactado composto por areia silte de tonalidade 10 YR 4/4, nessa unidade foram identificados seguintes vestígios arqueológicos: cerâmica, olaria, metal e vidro.

Cabe destacar que durante a terceira e quarta decapagem foram identificadas manchas nas regiões sudeste e noroeste da quadrícula, evidenciadas a profundidade de $20 \mathrm{~cm}$. Nesse momento a dinâmica de escavação nesta quadrícula foi alterada. Primeiro escavou-se a mancha noroeste, que englobava as quadrículas N933/L1072 e N934/L1072, para determinar seu comportamento no sítio, nela foram identificados materiais cerâmicos, que estavam queimados; e grande quantidade de carvão. Esta se encontrava na interface entre decapagem três e quatro. A mancha sudeste, não foi esvaziada até o término da 4 decapagem, sendo deixada intocada enquanto o restante da quadrícula estava sendo nivelada. Durante a escavação das quadrículas as machas foram protegidas/recobertas por plástico, desse modo o sedimento de uma área não contaminaria a da outra. Após o termino da quarta decapagem, (quando atingimos a interface entre as UE3 e EU5), a mancha sudeste foi escavada; nela encontramos grande quantidade de carvão e cerâmica. 
A quinta decapagem removeu o sedimento depositado entre 20 e $25 \mathrm{~cm}$ de profundidade, sendo referente a cota a partir da qual a Unidade Estratigráfica 5 (UE5) pode ser observada nesta quadrícula. A UE5 pode ser caracterizada como uma camada formada por sedimento compacto composto por areia argilosa de tonalidade 5 YR 5/6, na qual foram evidenciados fragmentos cerâmicos e de olaria.

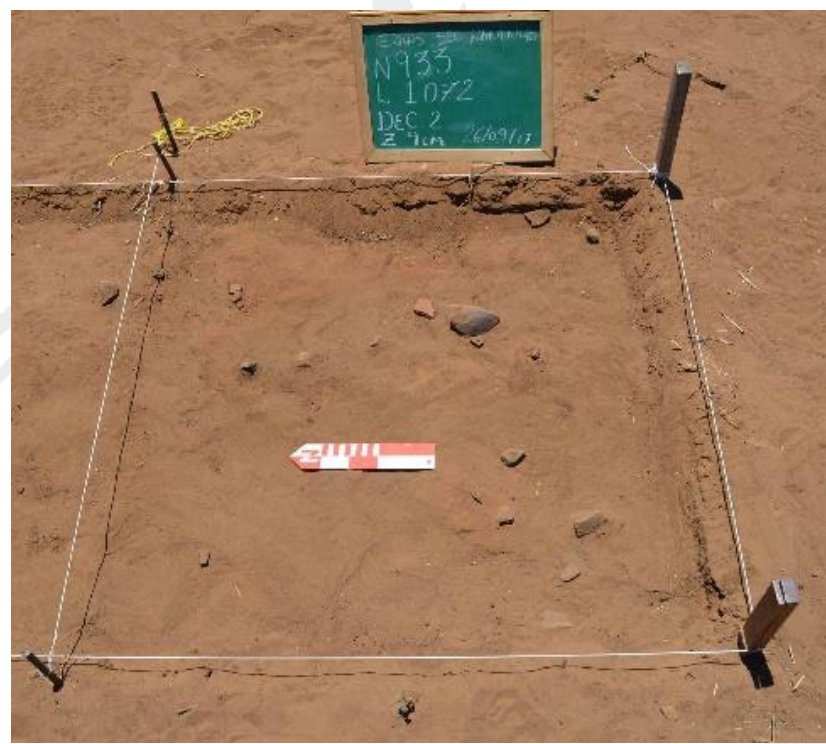

Figura 15: Quadricula N933 L1072. Decapagem 2, UE 2. Profundidade $9 \mathrm{~cm}$. Evidenciando fragmentos de cerâmicas simples e olaria.

$\mathrm{Na}$ quadrícula foram evidenciados um total de 463 artefatos arqueológicos (com a predominância de artefatos de cerâmica simples e olaria), fragmentos de carvão e coletadas amostras de sedimento das distintas UEs para análise laboratorial (Tabela 1). 


\begin{tabular}{|l|l|}
\hline Tipo de Artefato/Material & Quantidade \\
\hline Carvão & 1 \\
\hline Cerâmica Simples & 86 \\
\hline Lítico & 39 \\
\hline Metal & 52 \\
\hline Olaria & 255 \\
\hline Vidro & 16 \\
\hline Osso (Animal) & 12 \\
\hline Louça & 2 \\
\hline Plástico & 1 \\
\hline Sedimento & 2 \\
\hline Total & 466 \\
\hline
\end{tabular}

Tabela 1: Materiais identificados N933 L1072.

\section{Quadricula N934/L1072}

Nesta quadrícula efetuamos cinco decapagens atingindo a cota máxima de $25 \mathrm{~cm}$ de profundidade. A primeira decapagem atingiu a cota máxima de $6 \mathrm{~cm}$ de profundidade, demarcado assim o limite da Unidade Estratigráfica 1 (UE1), que pode ser caracterizada como uma camada formada por sedimento pulverulento composto por areia média de tonalidade 10YR 4/3 Brown. Durante o processo de decapagem foram evidenciados fragmentos de cerâmica e olaria.

A segunda decapagem removeu o sedimento depositado entre 6 e $10 \mathrm{~cm}$ de profundidade, sendo referente a cota que a Unidade Estratigráfica 2 (UE2) atinge 
nesta quadrícula. A UE2 pode ser caracterizada como uma camada formada por sedimento pouco compacto composto por areia silte de tonalidade 7.5YR 4/3 Reddish Brown. Durante o processo de decapagem foram observadas bioturbações causadas por plantas e insetos (raízes e casulo de insetos), e evidenciados fragmentos cerâmica, olaria, metal e vidro, além de e um provável fragmento de dente ou osso.

A terceira (entre 10 a $15 \mathrm{~cm}$ ) e, referem-se em grande parte a retirada de sedimentos associados a Unidade Estratigráfica 3 (EU3). A UE3 pode ser caracterizada como uma camada formada por por sedimento pouco compactado composto por areia silte de tonalidade $10 \mathrm{YR} 4 / 4$, nessa unidade foram identificados seguintes vestígios arqueológicos: cerâmica, olaria, vidro (Figura 17).

Cabe ressaltar que na profundidade de $15 \mathrm{~cm}$ foram observadas manchas no limite entre as quadrículas N933/L1072 e N934/L1072, tendo a escavação desta área seguindo os mesmos procedimentos descritos anteriormente. Durante a escavação das quadrículas as machas foram protegidas/recobertas por plástico, desse modo o sedimento de uma área não contaminaria a da outra. Após o termino da terceira decapagem, (quando atingimos a interface entre as UE3 e EU5), a mancha foi escavada; nela encontramos grande quantidade de carvão e cerâmica.

A quarta decapagem (entre 15 e $20 \mathrm{~cm}$ ) e a quinta decapagem (entre 20 e $25 \mathrm{~cm}$ ), referem-se em grande parte a retirada de sedimentos associados a Unidade 
Estratigráfica 5 (EU5). A UE5 pode ser caracterizada como uma camada formada por sedimento compacto composto por areia argilosa de tonalidade $5 \mathrm{YR} 5 / 6$, na qual foram evidenciados, apenas na decapagem 4, fragmentos cerâmicos e de olaria.

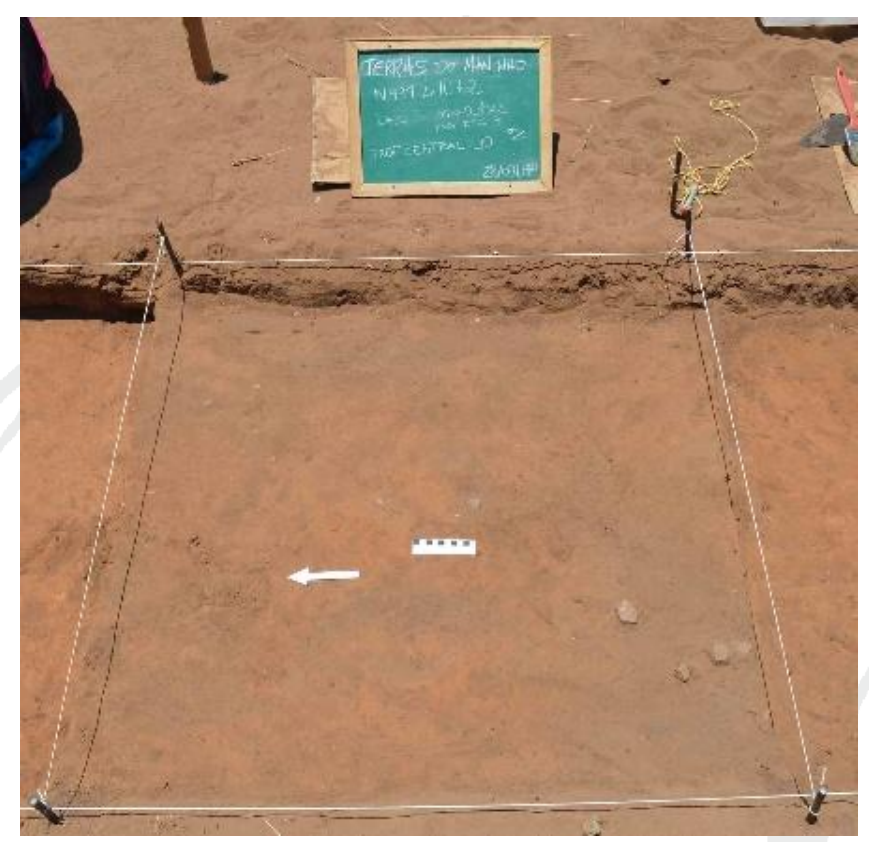

Figura 17: Quadricula N934 L1072. Decapagem 3, UE 3. Profundida $10 \mathrm{~cm}$.

$\mathrm{Na}$ referida quadricula foram coletados artefatos de cerâmica simples, olaria, fragmentos de carvão, ossos de animais, dentre outros materiais (Tabela 2). 


\begin{tabular}{|l|l|}
\hline Tipo de Artefato/Material & Quantidade \\
\hline Carvão & 2 \\
\hline Cerâmica Simples & 67 \\
\hline Lítico & 58 \\
\hline Metal & 16 \\
\hline Olaria & 161 \\
\hline Vidro & 10 \\
\hline Osso (Animal) & 25 \\
\hline Louça & 6 \\
\hline Não Identificado & 1 \\
\hline Total & 346 \\
\hline
\end{tabular}

Tabela2: Materiais identificados N934 L1072.

\section{Quadricula N935/L1072}

Nesta quadrícula efetuamos cinco decapagens, atingindo a cota máxima de $24 \mathrm{~cm}$ de profundidade. A primeira decapagem atingiu a cota máxima de $3 \mathrm{~cm}$ de profundidade, demarcado assim o limite da Unidade Estratigráfica 1 (UE1), que pode ser caracterizada como uma camada formada por sedimento pulverulento composto por areia média de tonalidade 10YR 4/3 Brown. Durante o processo de decapagem foram evidenciados fragmentos de cerâmica e olaria (telha e tijolo), e material lítico.

A segunda decapagem removeu o sedimento depositado entre 3 e $8 \mathrm{~cm}$ de profundidade, sendo referente a cota que a Unidade Estratigráfica 2 (UE2) atinge nesta quadrícula. A UE2 pode ser caracterizada como uma camada formada por 
sedimento pouco compacto composto por areia silte de tonalidade 7.5YR 4/3 Reddish Brown. Durante o processo de decapagem foram fragmentos de cerâmica, olaria (telha) e metal.

A terceira (entre 8 a $13 \mathrm{~cm}$ ), a quarta (entre 13 e $19 \mathrm{~cm}$ ) e a quinta decapagem (entre 19 a $24 \mathrm{~cm}$ ), referem-se a retirada de sedimentos associados a Unidade Estratigráfica 5 (UE5). A UE5 pode ser caracterizada como uma camada formada por sedimento compacto composto por areia argilosa de tonalidade $5 \mathrm{YR} 5 / 6 . \mathrm{Na}$ terceira decapagem foram evidenciados fragmentos de olaria, cerâmica e vidro; na quarta decapagem constatou-se a presença de bioturbação (Figura 18) e foram evidenciados fragmentos cerâmicos. Na quinta decapagem foram evidenciados apenas fragmentos cerâmicos.

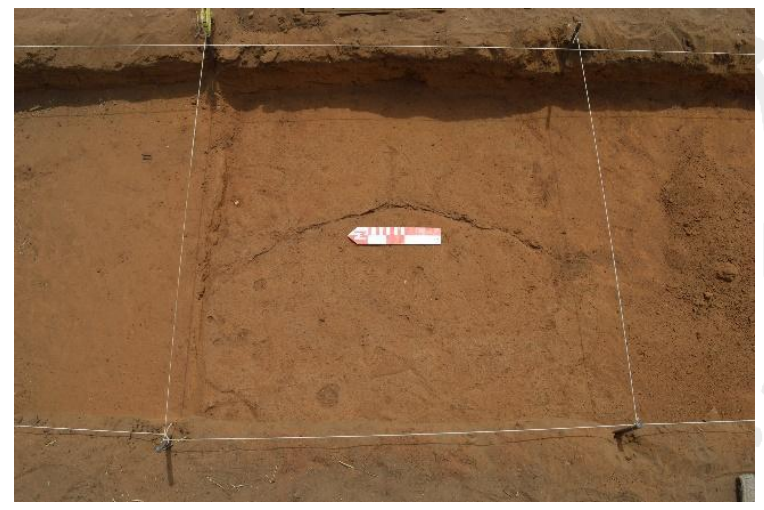

Figura 18: Quadricula N935 L1072.

Decapagem 4, UE 3. Profundidade 19 $\mathrm{cm}$. Bioturbação provocada por insetos. 
$\mathrm{Na}$ referida quadricula foi coletado um total de 193 artefatos arqueológicos, com predomínio de fragmentos de telha (Tabela 3). Também foi realizada a coleta de sedimentos (duas amostras, de duas UE distintas, para análises de laboratório.

\begin{tabular}{|l|l|}
\hline Tipo de Artefato/Material & Quantidade \\
\hline Cerâmica Simples & 29 \\
\hline Lítico & 16 \\
\hline Metal & 12 \\
\hline Olaria & 130 \\
\hline Vidro & 4 \\
\hline Sedimento & 2 \\
\hline Louça & 1 \\
\hline Não Identificado & 1 \\
\hline Total & 195 \\
\hline
\end{tabular}

Tabela 3: Artefatos identificado na quadrícula N935 L1072.

\section{Quadricula N936/L1072}

Nesta quadrícula efetuamos quatro decapagens, atingindo a cota máxima de $23 \mathrm{~cm}$ de profundidade. A primeira decapagem atingiu a cota máxima de $3 \mathrm{~cm}$ de profundidade, demarcado assim o limite da Unidade Estratigráfica 1 (UE1), que pode ser caracterizada como uma camada formada por sedimento pulverulento composto por areia média de tonalidade 10YR 4/3 Brown. Durante o processo de decapagem foram evidenciados fragmentos de cerâmica e olaria (telha e tijolo), e material lítico. 
A segunda decapagem (entre 3 e $8 \mathrm{~cm}$ ) e a terceira decapagem (entre 8 a $15 \mathrm{~cm}$ ), referem-se a retirada de sedimentos associados a Unidade Estratigráfica 2 (UE2).. A UE2 pode ser caracterizada como uma camada formada por sedimento pouco compacto composto por areia silte de tonalidade 7.5YR 4/3 Reddish Brown. Durante o processo de decapagem foram fragmentos de cerâmica, olaria (telha) e metal. Na segunda decapagem foram evidenciados fragmentos de cerâmica e olaria, além de um estojo de munição de arma de fogo, e um artefato em vidro com indício de retoque por pressão. Na terceira decapagem foram evidenciados fragmentos olaria (telha) e louça, além de material lítico e metal.

A quarta decapagem (entre 15 e $23 \mathrm{~cm}$ ), refere-se a retirada de sedimentos associados a Unidade Estratigráfica 5 (UE5). A UE5 pode ser caracterizada como uma camada formada por sedimento compacto composto por areia argilosa de tonalidade 5YR 5/6 (Figura 19). Na quarta decapagem constatou-se a presença de bioturbações causadas por raízes e não foram evidenciados objetos com interesse arqueológico.

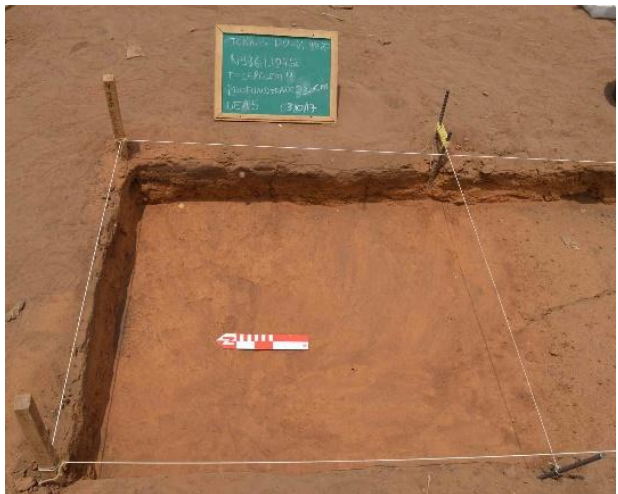

Figura 19: Quadricula N936 L1072.

Decapagem 4, UE 5. Profundidade $23 \mathrm{~cm}$.

Indexadores: Latindex, ISIS, Google Academic 
$\mathrm{Na}$ quadricula foram coletados um total de 204 artefatos arqueológicos, os tipos que predominaram foram os artefatos de olaria, lítico e cerâmica simples, respectivamente (Tabela 4$)$.

\begin{tabular}{|l|l|}
\hline Tipo de Artefato & Quantidade \\
\hline Cerâmica Simples & 31 \\
\hline Lítico & 38 \\
\hline Metal & 4 \\
\hline Olaria & 123 \\
\hline Vidro & 4 \\
\hline Osso (animal) & 4 \\
\hline Total & 204 \\
\hline
\end{tabular}

Tabela 4: Materiais identificados na quadra N936 L1072

\section{Setor Leste/Oeste}

No Setor Leste/Oeste foram escavadas as quadrículas N928/L1072, N928/L1073 , N928/L1074 e N928/L1075 a seguir apresentaremos, separadamente, os resultados das intervenções em cada uma destas quadrículas.

\section{Quadrícula N928/L1072}

Nesta quadrícula efetuamos nove decapagens atingindo a cota máxima de $42 \mathrm{~cm}$ de profundidade. A primeira decapagem atingiu a cota máxima de $3 \mathrm{~cm}$ de profundidade, demarcado assim o limite da Unidade Estratigráfica 1 (UE1), que pode ser caracterizada como uma camada formada por sedimento pulverulento composto por areia média de tonalidade 10YR 4/3 Brown. Durante o processo de 
decapagem foram evidenciados fragmentos de cerâmica, lítico, louça, olaria e metal.

A segunda (entre 3 e $8 \mathrm{~cm}$ ) e a terceira decapagem (entre 8 a 11,5), referem-se a retirada de sedimentos associados a Unidade Estratigráfica 2 (UE2). A UE2 pode ser caracterizada como uma camada formada por sedimento pouco compacto composto por areia silte de tonalidade 7.5YR 4/3 Reddish Brown.

Durante a segunda decapagem (Figura 20) foram evidenciados fragmentos de cerâmica, lítico, metal, olaria, carvão, osso, e vidro retocado; na terceira decapagem constatou-se a presença de bioperturbação e foram evidenciados fragmentos olaria (telha), cerâmica, metal e vidro; já na quarta decapagem não foram encontrados artefatos arqueológicos.

A quarta (entre 11,5 a 16), quinta (entre 16 a $21 \mathrm{~cm}$ ) e a sexta decapagem (entre 21 a $27 \mathrm{~cm}$ ), referem-se a Unidade Estratigráfica 3 (EU3). A UE3 pode ser caracterizada como uma camada formada por sedimento pouco compactado composto por areia silte de tonalidade 10 YR 4/4.

Nessa unidade estratigráfica foram evidenciados durante a quarta decapagem fragmentos de louça (grés), cerâmica, vidro, metal e olaria, e constatou-se a presença de bioperturbação; na quinta decapagem coletamos fragmentos cerâmica, material lítico e olaria; e na sexta decapagem encerrou em $27 \mathrm{~cm}$ de profundidade, 
evidenciamos fragmentos de olaria (telha), cerâmica, osso e material lítico, além de bioturbação causada por insetos (sendo um buraco com $5 \mathrm{~cm}$ de profundidade). A sétima (entre 27 a $32 \mathrm{~cm}$ ), a oitava (entre 32 a $37 \mathrm{~cm}$ ) e a nona decapagem ( 37 a $42 \mathrm{~cm}$ ), e a décima decapagem (entre 33 a $38 \mathrm{~cm}$ ) referem-se a retirada de sedimentos associados a Unidade Estratigráfica 5 (UE5). A UE5 pode ser caracterizada como uma camada formada por sedimento compacto composto por areia argilosa de tonalidade 5YR 5/6 yellowish reda.

Durante a sétima decapagem foram evidenciados fragmentos cerâmica e observou-se a continuidade das bioturbações; na oitava e nona decapagem não foram encontrados artefatos arqueológicos, mas continuamos a evidenciação a ação das bioturbações causadas por insetos no solo (um buraco com $9 \mathrm{~cm}$ de profundidade).

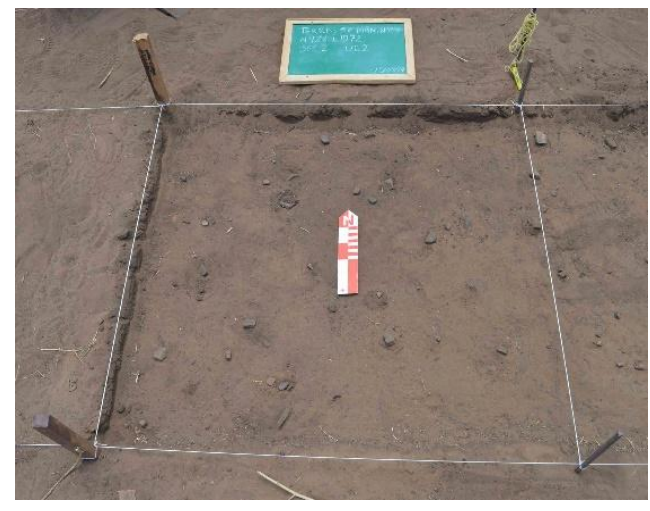

Figura 20: Quadricula N928 L1072.

Decapagem 2, UE 2. Profundidade 3-8 cm. 
$\mathrm{Na}$ referida quadricula foram coletados um total de 395 artefatos, também foi coletado sedimento de duas Unidades Estratigráficas (Tabela 5).

\begin{tabular}{|l|l|}
\hline Tipo de Artefato/Material & Quantidade \\
\hline Cerâmica Simples & 77 \\
\hline Grés & 1 \\
\hline Lítico & 45 \\
\hline Metal & 14 \\
\hline Olaria & 242 \\
\hline Osso (Animal) & 4 \\
\hline Restos Orgânicos & 1 \\
\hline Vidro & 10 \\
\hline Sedimento & 2 \\
\hline Total & 396 \\
\hline
\end{tabular}

Tabela 5: Materiais Identificados na quadrícula N925 L1072.

\section{Quadrícula N928/L1073:}

Nesta quadrícula efetuamos sete decapagens atingindo a cota máxima de $28 \mathrm{~cm}$ de profundidade. A primeira decapagem atingiu a cota máxima de $3 \mathrm{~cm}$ de profundidade, demarcado assim o limite da Unidade Estratigráfica 1 (UE1), que pode ser caracterizada como uma camada formada por sedimento pulverulento composto por areia média de tonalidade 10YR 4/3 Brown. Durante o processo de decapagem foram evidenciados fragmentos de olaria (telha), vidro, metal e material lítico, e constatada bioturbações causadas por raízes. 
A segunda (entre 3 e $8 \mathrm{~cm}$ ) e a terceira decapagem (entre 8 a 9cm), referem-se a retirada de sedimentos associados a Unidade Estratigráfica 2 (UE2). A UE2 pode ser caracterizada como uma camada formada por sedimento pouco compacto composto por areia silte de tonalidade 7.5YR 4/3 Reddish Brown.

Durante a segunda decapagem foram evidenciados fragmentos cerâmica, lítico, metal, olaria (telha) e vidro; na terceira decapagem constatou-se a presença de bioperturbação por raízes e foram evidenciados fragmentos olaria (telha) e cerâmica.

A quarta (entre 9 a $16 \mathrm{~cm}$ ), quinta (entre 14 a $9 \mathrm{~cm}$ ) e a sexta decapagem (entre 19 a 24cm), referem-se a Unidade Estratigráfica 3 (EU3). A UE3 pode ser caracterizada como uma camada formada por sedimento pouco compactado composto por areia silte de tonalidade $10 \mathrm{YR}$ 4/4.

Nessa unidade estratigráfica foram evidenciados durante a quarta decapagem fragmentos de cerâmica, metal, olaria (telha) e material lítico, e constatou-se a presença de bioperturbação causada por insetos (Figura 21); na quinta decapagem coletamos fragmentos cerâmica, vidro, material lítico e metálico; e na sexta decapagem encerrou evidenciamos fragmentos de cerâmica, vidro, material lítico e metálico. Cabe ressaltar que durante a quarta decapagem foi evidenciada uma mancha no sentido norte da quadricula a aproximadamente $11,5 \mathrm{~cm}$ de profundidade. A mancha foi escavada separadamente e atingiu a cota de $13 \mathrm{~cm}$ de 
profundidade, contatou-se que tal mancha era proveniente de uma bioturbação (insetos).

A sétima (entre 24 a $28 \mathrm{~cm}$ ) refere-se a retirada de sedimentos associados a Unidade Estratigráfica 5 (UE5). A UE5 pode ser caracterizada como uma camada formada por sedimento compacto composto por areia argilosa de tonalidade $5 \mathrm{YR}$ $5 / 6$ yellowish red. Durante a sétima decapagem foram evidenciados fragmentos de cerâmica e material lítico.

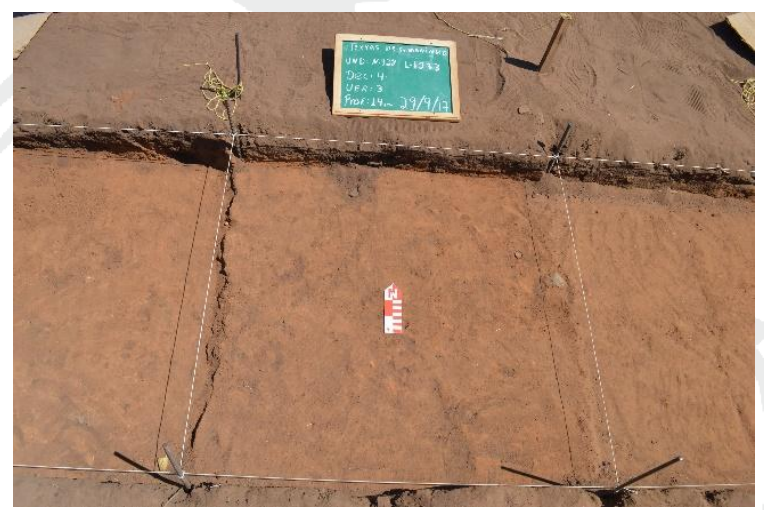

Figura 21: Quadricula N928 L1073.

Decapagem 4, UE 3, profundidade 9$16 \mathrm{~cm}$.

Na referida quadricula foram coletados um total de 324 artefatos, dentre eles a maior concentração é de fragmentos de olaria (principalmente telha) e cerâmica simples (Tabela 6). 


\begin{tabular}{|l|l|}
\hline Tipo de Artefato & Quantidade \\
\hline Louça & 2 \\
\hline Cerâmica Simples & 98 \\
\hline Lítico & 51 \\
\hline Metal & 19 \\
\hline Olaria & 149 \\
\hline Vidro & 4 \\
\hline Osso & 1 \\
\hline Total & 324 \\
\hline
\end{tabular}

Tabela 6: Artefatos identificados na quadrícula 928 L1073.

\section{Quadrícula N928/L1074}

Nesta quadrícula efetuamos dez decapagens atingindo a cota máxima de $38 \mathrm{~cm}$ de profundidade. A primeira decapagem atingiu a cota máxima de $1 \mathrm{~cm}$ de profundidade, demarcado assim o limite da Unidade Estratigráfica 1 (UE1), que pode ser caracterizada como uma camada formada por sedimento pulverulento composto por areia média de tonalidade 10YR 4/3 Brown. Durante o processo de decapagem foram evidenciados fragmentos de cerâmica e vidro.

A segunda (entre 1 e $6 \mathrm{~cm}$ ), a terceira (entre 6 a 9), e a quarta decapagem (9 a 10,5 $\mathrm{cm})$ referem-se a retirada de sedimentos associados a Unidade Estratigráfica 2 (UE2). A UE2 pode ser caracterizada como uma camada formada por sedimento pouco compacto composto por areia silte de tonalidade 7.5YR 4/3 Reddish Brown. 
Durante a segunda decapagem foram evidenciados fragmentos olaria (telha), vidro

e carvão; na terceira decapagem foram evidenciados fragmentos olaria (telha), cerâmica, e material lítico (Figura 22); já na quarta decapagem não foram encontrados artefatos arqueológicos.

A quinta (entre 10,5 a 14,5cm) e a sexta decapagem (entre 14,5 a 18,5cm), referem-se a Unidade Estratigráfica 3 (EU3). A UE3 pode ser caracterizada como uma camada formada por sedimento pouco compactado composto por areia silte de tonalidade $10 \mathrm{YR}$ 4/4. Nessa unidade estratigráfica foram evidenciados fragmentos de cerâmica e material lítico somente durante a quinta decapagem.

A sétima (entre 18,5 a $23 \mathrm{~cm})$, a oitava (entre 23 a $28 \mathrm{~cm})$, a nona (28 a $33 \mathrm{~cm})$, e a décima decapagem (entre 33 a $38 \mathrm{~cm}$ ) referem-se a retirada de sedimentos associados a Unidade Estratigráfica 5 (UE5). A UE5 pode ser caracterizada como uma camada formada por sedimento compacto composto por areia argilosa de tonalidade 5YR 5/6, na qual foram evidenciados fragmentos cerâmicos e de olaria. Durante a sétima decapagem foram evidenciados fragmentos cerâmica e material lítico (micaxisto) e ósseo; na oitava decapagem foram evidenciados fragmentos de cerâmica e vidro, e material lítico (lasca) e ósseo; já na nona e na décima decapagem não foram encontrados artefatos arqueológicos. 


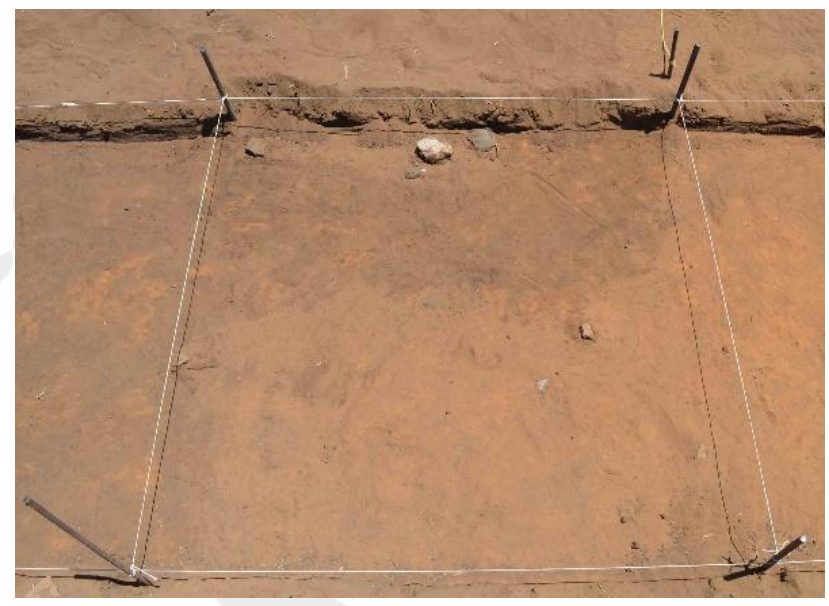

Figura 22: Quadricula N928

L1074. Decapagem 3, UE 2, profundidade $1-6 \mathrm{~cm}$.

$\mathrm{Na}$ quadricula foi coletado um total de 283 artefatos, que e em sua maioria corresponde a fragmentos de cerâmica simples e olaria (Tabela 7).

\begin{tabular}{|l|l|}
\hline Tipo de Artefato & Quantidade \\
\hline Grés & 1 \\
\hline Cerâmica Simples & 128 \\
\hline Lítico & 20 \\
\hline Metal & 4 \\
\hline Olaria & 118 \\
\hline Vidro & 6 \\
\hline Osso (Animal) & 6 \\
\hline Total & 283 \\
\hline
\end{tabular}

Tabela 7: Artefatos identificados na quadrícula N928 L1074. 


\section{Quadrícula N928/L1075}

Nesta quadrícula efetuamos dez decapagens. A primeira decapagem encerrou em $5 \mathrm{~cm}$ de profundidade; o sedimento apresentava em sua composição areia média, a tonalidade do sedimento é 10YR 4/3 de acordo com o Munssel, com compactação purvelenta. Constatou-se raízes tanto na primeira camada como na UE1. Coletamos os seguintes vestígios arqueológicos: cerâmica, louça e telha.

A segunda decapagem atingiu a profundidade de $4 \mathrm{~cm}$; constatou-se a uma unidade estratigráfica - UE3, uma mancha com tonalidade clara. Coletamos os seguintes vestígios arqueológicos: olaria, cerâmica, metal, osso e lítico.

A terceira decapagem encerrou em $9 \mathrm{~cm}$ de profundidade. Identificamos duas unidades estratigráficas - UE2 e UE3. Os vestígios encontrados na UE2 estão possivelmente associados a bioturbação. Coletamos os seguintes vestígios arqueológicos: olaria e cerâmica.

A decapagem quarta encerrou em $14 \mathrm{~cm}$ de profundidade. Identificamos a UE5, vale frisar que a UE4 surgiu no Setor Norte Sul. Coletamos os seguintes vestígios arqueológicos: estilha, olaria, cerâmica e vidro. A quinta decapagem encerrou em $19 \mathrm{~cm}$ de profundidade. Coletamos os seguintes vestígios arqueológicos: cerâmica, cerâmica regional, olarias e líticos (Figuras 23 e 24). A sexta decapagem encerrou em $24 \mathrm{~cm}$ de profundidade. Coletamos os seguintes vestígios arqueológicos: olaria, cerâmica regional e lítico. A sétima decapagem encerrou em $29 \mathrm{~cm}$ de profundidade. Coletamos os seguintes vestígios arqueológicos: cerâmica regional 
e olaria. A oitava decapagem encerrou em $34 \mathrm{~cm}$ de profundidade. Coletamos cerâmica regional. Na nona decapagem encerrou em $39 \mathrm{~cm}$ de profundidade. Coletamos os seguintes vestígios arqueológicos: cerâmico regional e lítico. $\mathrm{Na}$ décima decapagem encerrou em $44 \mathrm{~cm}$ de profundidade. Constatou que a UE5, a bioturbação de raízes e as manchas permaneceram até a décima decapagem.
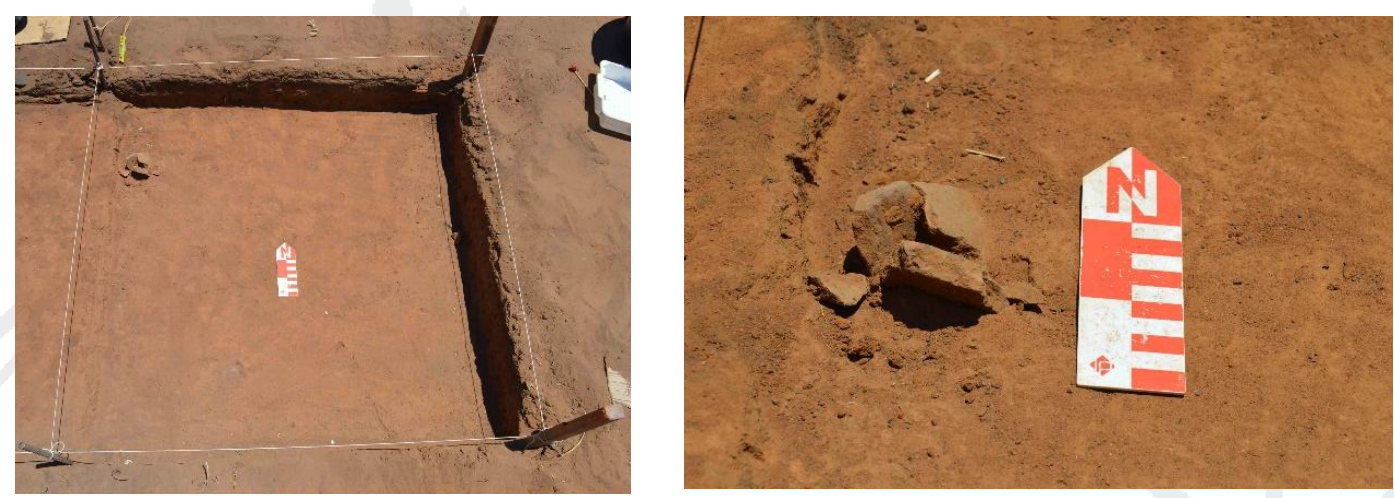

Figura 23 e 24: Quadricula N928 L1075. Decapagem 5, EU 5, profundidade 14-19 cm.

Na quadricula N928 L1075 foi coletado um total de 200 artefatos, assim como nas outras quadriculas temos a predominância de cerâmica simples e olaria (Tabela 8). Também foram coletadas 3 amostras de sedimentos de UE distintas para analise em laboratório. 


\begin{tabular}{|l|l|}
\hline Tipo de Artefato/Material & Quantidade \\
\hline Borracha & 1 \\
\hline Cerâmica Simples & 80 \\
\hline Lítico & 2 \\
\hline Louça & 1 \\
\hline Olaria & 100 \\
\hline Vidro & 12 \\
\hline Osso (Animal) & 1 \\
\hline Sedimento & 3 \\
\hline Metal & 3 \\
\hline Total & 203 \\
\hline
\end{tabular}

Tabela 8: Artefatos identificados na quadrícula N928 L1075.

\section{O PROJETO SÍTIO ESCOLA TERRA DE CALDEIRÃOZINHO E A} ARQUEOLOGIA DO PRESENTE

Os materiais arqueológicos até agora encontrados no âmbito do projeto terras de Caldeirãozinho, embora contemplem líticos e cerâmicas que poderiam se relacionar à produção indígena pré-colonial, são em sua maioria, até o momento, correspondentes a um período e dinâmica de ocupação que se estende do século XVIII até o presente ${ }^{6}$.

\footnotetext{
${ }^{6}$ Nos sítios identificados, assim como na área escavada, as técnicas construtivas e o processo de construção, reutilização e abandono da área podem ser associados a comunidades que, segundo a bibliografia consultada, se enquadraram no contexto das comunidades sertanejas. No aspecto construtivo predominam materiais oferecidos pelo meio-ambiente com a pedra (alicerces, divisões internas), a madeira (portas, janelas) e a terra (reboco). De acordo com Abreu (2015), a utilização do barro mantém-se como técnica ainda hoje, logo, tal manutenção deve ser entendida para além da dificuldade de obtenção de outras matérias primas e de poder aquisitivo, e ser compreendida como um aspecto importante dos saberes e fazeres de grupos campesinos e/ou sertanejos.
} 
Não raro, nas conversas e prosas vivenciadas com membros da comunidade ouvem-se histórias que remontam ao período de expansão da produção pecuária, sejam em histórias de travessias do estado tocando o gado, sejam em histórias que narram a constituição familiar a partir do aprisionamento de mulheres indígenas e ainda aquelas que versam sobre a luta e a guerra com grupos indígenas.

Sendo a sugestão dada pela oralidade e pela materialidade arqueológica regional efetivamente correspondente a uma realidade da dinâmica de ocupação, ou não, fato é que os sítios que encontramos nos remetem a um passado tão recente na vida da comunidade de Jatobá dos Ferros, que o mesmo rompe a fronteira cartesiana do tempo, e se mistura ao presente. O passado, à medida que se diz da vida do pai, do avô, e da vida dos que ali vivem hoje, parece-nos ser tão hoje quanto o amanhã. Temos assim, um contexto arqueológico que poderia ser entendido e abordado a partir do que é chamado de uma "arqueologia do presente" (GONZALES-RUIBAL, 2009; SILVA, 2017), e para o qual a variável temporal seja efetivamente secundária diante do estudo da materialidade (GONZALESRUIBAL, 2006; 2014; HAMILAKIS, 2015).

A arqueologia do presente, segundo Silva (2017), nasce com viés político delimitado em que a ideia de uma arqueologia medida a partir de um critério temporal e que coloca comunidades inteiras e grupos culturais como interessantes apenas enquanto "relíquias do passado" (GONZALES-RUIBAl, 2009) é questionada: 
A arqueologia do presente toma uma postura crítica ante essa situação e incorpora como parte de seus objetivos abordar questões relacionadas com a globalização, a violência política, os programas de desenvolvimento e as ingerências estatais na vida das comunidades estudadas (GONZALES-RUIBAL, 2009:21).

Outrossim, entender o contexto arqueológico das Terras de Caldeirãozinho enquanto uma arqueologia do presente nos permite, ao mesmo tempo que demanda, compreender a relação entre a materialidade patrimonializada e a comunidade: os modos como a primeira é (re)significada pela segunda, como ambas se constroem e se modificam. Tal demanda e permissividade nos coloca em diálogo com as ideias da arqueologia pública, lançando desafios e possibilidades que parecem traçar um caminho de maior fluxo entre o conhecimento científico acadêmico e aquele dito tradicional (CARNEIRO DA CUNHA, 2014).

\section{O PROJETO SÍTIO ESCOLA TERRAS DE CALDEIRÃOZINHO E SEU CONTEXTO DIDÁTICO-PEDAGÓGICO}

Uma das primeiras dificuldades encontradas na elaboração de um projeto que tenha como objetivo principal as práticas didático-pedagógicas no ensino da arqueologia está na possibilidade de se equacionar as demandas do órgão fiscalizador com práticas de ensino.

O patrimônio cultural arqueológico é regido por leis a fim de se garantir a pesquisa de responsabilidade e a salvaguarda deste patrimônio. Com fins ilustrativos e reflexivos temos a lei 3.924 de 26 de Julho 1961, a Carta Magna de 
1988, a Portaria $n^{\circ} 230$ de 2002 do IPHAN, a instrução Normativa 01/2016 preocupadas em garantir os procedimentos mínimos de proteção do patrimônio.

Tem-se aí um primeiro gargalo que demonstra uma certa incompatibilidade entre a legislação, a práxis legal e fiscalizadora do órgão competente e as atividades de ensino: embora seja a lei 3.924 de 1961 a responsável por reger as pesquisas arqueológicas acadêmicas, a partir da publicação da instrução normativa (criada com fins de regular as atividades de pesquisa realizadas no âmbito da Arqueologia vinculada a processos de licenciamento ambiental), diversas superintendências passam a adotá-la como norteadora para avaliação de projetos, incluindo os acadêmicos. Deste modo, o caráter didático-pedagógico de um projeto sítio escola é quase que invisibilizado por documentações e reflexões que mascaram o pano de fundo que justifica o próprio projeto: o ensino e a aprendizagem.

Da mesma maneira, a preocupação - necessária - em se salvaguardar as informações dos registros arqueológicos nos coloca uma outra questão: o processo de aprendizagem envolve o erro, o engano. Como lidar com os erros, as perdas, os equívocos inerentes ao aprendizado em relação ao patrimônio cultural? Como equacionar a proteção do patrimônio com a garantia de uma aprendizagem e todos os seus processos? Ao mesmo tempo em que estes questionamentos parecem travar ou dificultar uma perspectiva de ensino e aprendizagem em sítios arqueológicos não emulados ou inventados, defende-se uma ideia de que não se faz salutar a formação de arqueólogos a partir apenas de aulas teóricas ou de 
escavações em caixas com estratigrafias falseadas - por mais criativas que possam ser. Como formar um arqueólogo capaz de lidar com as realidades das "coisas" dos arqueólogos (HILBERT, 2009), com as necessidades de mudanças metodológicas sugeridas pela realidade contextual dos objetos, paisagem e espaço sem a experiência tácita do campo? Qual seria o equivalente ao "Anthropological Blues $^{7 "}$ " dos estudantes de arqueologia sem a experiência no sítio arqueológico? Em que medida o conceito de patrimônio, e, portanto, dos mecanismos legais de sua proteção, não exclui a possibilidade didática do sítio arqueológico enquanto também processo (uma vez que o sítio só se faz sítio porque assim o categorizamos: sítio arqueológico só passa a existir no momento em que agem cientistas e Estado Nacional)? E ainda, porque a função didática do patrimônio cultural está quase que somente reservada aos museus?

Cremos, e militamos institucionalmente, para não só a manutenção, mas ampliação dos espaços de práticas acadêmicas em que sejam possibilitadas ao estudante a reflexão, construção e desconstrução de ideias e conteúdos teóricos e restritos a sala de aula por meio de atividades de campo.

Em diálogo com referências nas discussões de processos de ensino e aprendizagem, bem como da construção do conhecimento, como Vygostky (1984; 1999), Piaget (1972), Merleau-Ponty (1999), Maturana (2001) e Ingold (2011), cremos que é na experiência, nas relações entre coisas e coisas, coisas e pessoas, e

\footnotetext{
${ }^{7}$ Referência aqui ao Anthropological Blues de Roberto da Matta em “O ofício do etnólogo"(1978).
} Indexadores: Latindex, ISIS, Google Academic 
pessoas e pessoas que o conhecimento é gerado. Assim, o conhecimento arqueológico deve incluir atividades que permitam aos estudantes experimentar a evidenciação ou delineamento de um perfil estratigráfico a partir também do barulho da colher de pedreiro ou do enxó no sedimento; que permitam o caminhar repetitivo no sítio arqueológico percebendo a mudança da direção do vento, do caminhar do sol ao longo do dia; que permitam ao corpo a experiência da prática arqueológica.

Entendemos, portanto, que a experiência de campo ajuda a romper com práticas positivistas nas quais:

O fracasso das ações pedagógicas assentadas na concepção positivista de aprendizagem, as quais silenciam os alunos, isolam-nos e os submetem à autoridade do saber dos professores, dos conferencistas, dos textos, dos livros, das instruções programadas, das normas ditatoriais da instituição, e tudo isso para chegar a um único resultado: o falso conhecimento e à subordinação (GIUSTA, 2013:26).

O entendimento do conhecimento enquanto processo, experiências, ciclos hermenêuticos, redes, fenômenos, fluxos... devolve ao indivíduo pesquisador a autoria de seu conhecimento, um conhecimento que é também corporificado (MERLAU-PONTY, 1999). A subjetividade, assim como os diálogos interontologias e entre-ontologias é novamente validada no fenômeno de percepção do mundo, e, portanto, de possibilidade de ação entre eles. 


\section{REFERÊNCIAS BIBLIOGRÁFICAS}

ABREU e SOUZA, R. 2015. "Globalização, Consumo e Diacronia: Populações sertanejas sob a ótica da Arqueologia". Vestígios: revista latino-americana de arqueologia histórica. vol.9 (2), $35-62$.

BICHO, N. F. 2006. Manual de Arqueologia Pré-Histórica. Lisboa: Edições 70.

CARNEIRO DA CUNHA, M. 2014. Cultura com Aspas. São Paulo: Editora Cosac-Naif. DA MATTA, R. 1978. "O Ofício do Etnólogo. Boletim do Museu Nacional. Antropologia”. No 27, 1-12

FONTANA, B. L. 1965. "On the meaning of historic sites archaeology". American Antiquity. vol. 31 (1), 61-65.

GIUSTA, A. S. 2013. “Concepções de aprendizagem e práticas pedagógicas”. Educ. rev. [online], vol.29 (1), 20-36.

GONZALEZ-RUIBAL, A. 2006. "The Past is Tomorrow. Towards an Archaeology of the Vanishing Present". Norwegian Archaeological Review, vol 39 (2), 110-125.

GONZALEZ-RUIBAL, A. 2009. "De la Etnologia a la Arqueologia del Presente". In: SALAZAR, J. et all (coords). Mundos Tribales. Ua visión etonoarqueologica. Valencia: Museu Arqueologico de Valencia. 6-27

GONZALES-RUIBA1, A. 2014. "Malos nativos. una crítica de las arqueologías indígenas y poscoloniales". Revista de Arqueologia. Sociedade de Aqrueologia Brasileira. vol. 27 (2).

HARRIS, E. C. 1991. Principios de Estratigrafía Arqueológica. Barcelona: Editorial Crítica.

HILBERT, K. 2009. "Diálogos entre substâncias, cultura material e palavras". MÉTIS: história \& cultura, vol.8 (16), 11-25.

INGOLD, T. 2011. "Epilogue: Anthropology is not Ethnography." In: Being Alive. London and New York: Routledge. 229-243. 
MATURANA R., Humberto (org). 2001. Cognição, ciência e vida cotidiana. Belo Horizonte: Ed. UFMG.

MERLEAU-PONTY, M. 1999. Fenomenologia da Percepção. São Paulo: Martins Fontes.

PIAGET. J. A evolução intelectual da adolescência à vida adulta. Porto Alegre: Faculdade de Educação, 1993. Traduzido de: Intellectual Evolution from Adolescence to Adulthood. Human Development, v. 15, p. 1-12, 1972.

SANJUÁN, L. 2005. Introduccíon al reconocimiento y análisis arqueológico del território. Barcelona: Arial.

SILVA, L. A. da. 2017. "( $(\mathrm{Re})$ visitando as pessoas e as coisas. A Etnoarqueolohia enquanto uma Arqueologia do Presente”. Revista de Arqueologia. vol.30 (1), 175-185.

VEIGA, L.A.K.; ZANETTI, M. A.Z.; FAGGION, P.L. 2012. Fundamentos de Topografia. Curitiba: UFPR.

VYGOTSKY, L. S. 1984. A formação social da mente. São Paulo: Martins Fontes.

VYGOTSKY, L. S. 1999. Teoria e método em psicologia. 2.ed. São Paulo: Martins Fontes. 